\title{
Environmental efficiency of alternative dairy systems: A productive efficiency approach
}

\author{
L. Toma, ${ }^{*}$ M. March,$\dagger^{1}$ A. W. Stott, $\ddagger$ and D. J. Roberts $†$ \\ *Land Economy and Environment Group, Scotland's Rural College (SRUC), King's Buildings, West Mains Road, Edinburgh, EH9 3JG, \\ United Kingdom \\ †Future Farming Systems Group, SRUC, Hestan House, The Crichton Business Park, Dumfries, DG1 4TA, United Kingdom \\ ¥Future Farming Systems Group, SRUC, King's Buildings, West Mains Road, Edinburgh, EH9 3JG, United Kingdom
}

\section{ABSTRACT}

Agriculture across the globe needs to produce "more with less." Productivity should be increased in a sustainable manner so that the environment is not further degraded, management practices are both socially acceptable and economically favorable, and future generations are not disadvantaged. The objective of this paper was to compare the environmental efficiency of 2 divergent strains of Holstein-Friesian cows across 2 contrasting dairy management systems (grazing and nongrazing) over multiple years and so expose any genetic $\times$ environment $(\mathrm{G} \times \mathrm{E})$ interaction. The models were an extension of the traditional efficiency analysis to account for undesirable outputs (pollutants), and estimate efficiency measures that allow for the asymmetric treatment of desirable outputs (i.e., milk production) and undesirable outputs. Two types of models were estimated, one considering production inputs (land, nitrogen fertilizers, feed, and cows) and the other not, thus allowing the assessment of the effect of inputs by comparing efficiency values and rankings between models. Each model type had 2 versions, one including 2 types of pollutants (greenhouse gas emissions, nitrogen surplus) and the other 3 (greenhouse gas emissions, nitrogen surplus, and phosphorus surplus). Significant differences were found between efficiency scores among the systems. Results indicated no $\mathrm{G} \times \mathrm{E}$ interaction; however, even though the select genetic merit herd consuming a diet with a higher proportion of concentrated feeds was most efficient in the majority of models, cows of the same genetic merit on higher forage diets could be just as efficient. Efficiency scores for the low forage groups were less variable from year to year, which reflected the uniformity of purchased concentrate feeds. The results also indicate that inputs play an important role in the measurement of environmental efficiency of dairy systems and that animal health variables (incidence of udder health disorders and body condition

Received April 10, 2013

Accepted August 5, 2013.

${ }^{1}$ Corresponding author: maggie.march@sruc.ac.uk score) have a significant effect on the environmental efficiency of each dairy system. We conclude that traditional narrow measures of performance may not always distinguish dairy farming systems best fitted to future requirements.

Key words: environmental efficiency, experimental dairy farm, nonparametric data envelopment analysis

\section{INTRODUCTION}

During the second half of the 20th century, the agriculture industry harnessed technology that has resulted in crop and animal productivity increases of around $2 \%$ per annum (Duvick, 1986; Ludena et al., 2007), mainly from advances in genetics, management practices, and forage improvements (Pryce et al., 2004). However, significant challenges are yet to be addressed, as global warming effects are apparent and unsustainable food production systems are causing environmental degradation (Foresight, 2011). Against a background of population growth and food security concerns at the global level, the UK population is forecasted to increase by $14 \%$ by 2033 (ONS, 2012); if productivity gains continue at the same rate, then UK domestic demands could be met. However, UK dairy farming has been in decline for over 30 yr. During this time, the national milking herd has contracted by $43 \%$ (since 1980), yet efficiency has increased as total UK production fell by $20 \%$ over the same time period (Defra, 2011). Average UK yields per cow continue to increase while the overall number of farms continues to decrease (DairyCo, 2011). In addition to population growth and environmental concerns, further challenges for the future of food production include increased competition for land, energy, and water resources; maintaining food security; and managing changes in consumer behavior. These forces of change require the food system to be radically redesigned to achieve production in the long term (Foresight, 2011), but which dairy systems are optimal for delivering milk production that is sustainable?

In global terms, milk production systems are responsible for approximately $2.7 \%$ of all anthropogenic greenhouse gas emissions. As demand for dairy and 
meat products is expected to double by 2050 , it is crucial for the dairy industry to aim toward more sustainable low-carbon methods of production (FAO, 2010). Dairy systems are also a source of nutrient losses to the wider environment. Livestock excrete nitrogen $(\mathrm{N})$ and phosphorus $(\mathrm{P})$, which have ecological impacts (Erisman et al., 2007), such as water pollution caused by nitrate leaching, eutrophication of surface waters due to $\mathrm{N}$ and $\mathrm{P}$ enrichment, and soil acidification and plant damage from ammonia emissions (Amon et al., 2011). Moreover, the Haber process used to manufacture $\mathrm{N}$ is energy intensive, which incurs $\mathrm{CO}_{2}$ emissions, and $\mathrm{P}$ is a nonrenewable, depleting resource.

Sources of pollutants arising from dairy farms and associated mitigation strategies are well researched (Defra, 2008; DairyCo, 2009; FAO, 2010) and should be implemented dependent upon system type, location, and historical land use (IPCC, 2007). The focus on food security and climate change has led to increased attention on the measurement of both economic and environmental performance of agricultural production systems. Evidence regarding differences in the overall environmental impact created by a range of dairy farming systems could be improved as there is a need for evaluation of the differences between total resource use across different dairy systems (Alvis et al., 2012). Comparative analysis on the effect of dairy management systems that favor livestock on pasture land or not would aid the understanding of livestock sector impacts (Anderson and Gundel, 2011).

This study applied data envelopment analysis (DEA) to measure relative differences in the environmental efficiency of grazing and nongrazing dairy systems across 2 genetic lines of cows to investigate any genotype $\times$ environment $(\mathbf{G} \times \mathbf{E})$ interaction and to determine the wider environmental impact of each of the livestock systems while taking milk production into consideration. Types and amounts of undesirable outputs associated with each of the systems were evaluated and compared to identify possible options for mitigation of pollutants, because future legislation may require environmental externalities to be accounted for and reduced. In addition, the analysis estimated changes in the environmental efficiency of each system over time and the effect of independent variables on the efficiency of each system.

\section{MATERIALS AND METHODS}

\section{Langhill Feeding Experiments}

Data were obtained from the Langhill herd (Crichton Research Farm, Dumfries, Scotland) of Holstein-Friesian dairy cows, which are part of a long-term experiment to assess genetic line $\times$ feeding system interactions (Pol- lott and Coffey, 2008). The herd represents a range of dairy management methods in terms of breeding and feeding systems, and consists of 2 contrasting genetic lines, selected either for increased milk fat plus CP yield (select line, $\mathbf{S}$ ) or to remain close to the average genetic merit for milk fat plus CP yield for HolsteinFriesians evaluated annually in the United Kingdom (control line, C; Pryce et al., 1999).

During the experiment, cows were allocated to either a low forage ( $\mathbf{L F}$ ) diet consuming $3.0 \mathrm{t}$ of concentrate annually or a high forage (HF) diet containing approximately 1.2 t of concentrate (Chagunda et al., 2009). The LF cows remained indoors (i.e., nongrazing), whereas the HF cows were grazed when possible. Both groups were managed so that calving took place all year round. The feeding systems within the herd were defined as low forage control (LFC), low forage select (LFS), high forage control (HFC), and high forage select (HFS). Approximately 50 cows in each of the 4 groups were fed a TMR plus concentrate in the milking parlor. Forages fed in both LF and HF diets included grass silage, maize silage, and whole-crop wheat silage. Diets within LF herds consisted of approximately $47 \%$ forage, and in the winter months, the HF herd was housed and fed $75 \%$ forage on a DM basis (Chagunda et al., 2009). Diets were formulated to provide adequate $\mathrm{ME}$ and $\mathrm{CP}$ to meet the requirements of a cow within each genetic line $\times$ feeding system (Pollott and Coffey, 2008).

\section{Data}

The data set used in this analysis consisted of variables from all cows within the experiment between 2004 and 2010, irrespective of their health. Variables were extracted from the database for each cow and aggregated annually at the 4 system levels. Daily milk yields were the sum of 3 milkings daily, and 3-times-daily fat and $\mathrm{CP}$ concentrations of the milk were analyzed once per week and averaged. Cows were fed ad libitum, and feed intakes for those cows indoors were recorded for lactating cows using Hoko automatic feed measurement gates (Insentec BV, Marknesse, the Netherlands). Data regarding milk yield, fertilizer application, energy use, and diet were extracted directly from the database, and data for herd dynamics were taken from an annual inventory of the systems. The protocol of the experiment required that cows were kept in the herd for at least 3 lactations unless cow welfare dictated that culling was necessary. Cows could remain in the herd for more than 3 lactations if a suitable heifer of the same genetic line was not available. Culling time was defined as the date on which a cow's productive life ceased, and cows had a maximum of 7 chances to conceive before being culled. 
Carbon Footprints. The PAS2050-accredited SAC Carbon Calculator v3.11 (SAC, 2011) was used to estimate greenhouse gas (GHG) emissions attributed to each of the 4 groups. The calculator uses IPCC (2007) Tier 2 methodologies, equations, and emission factors, and requires detailed information regarding farm inputs and outputs related to livestock, land and crops, purchased feeds, and energy use. Herd dynamic inputs required an annual reconciliation of all ages of livestock taking into consideration sales, purchases, and culling of cows. A summation of home-grown and purchased feeds was footprinted per type and manure management practices were expressed depending on the amount of time the cows spent grazing or housed. Hectares of land required and fertilizer applications were allocated on a per-crop and fertilizer-type basis, which allowed the calculation of emissions of direct and indirect $\mathrm{CO}_{2}$ as well as nitrous oxide released following decomposition of crop residue in the soil. Use of petrol and diesel was recorded in the database; however, electricity $(\mathrm{kWh})$ was estimated from milk yield (Sheane et al., 2010) as there was no on-farm electricity meter. Sprays of pesticides, fungicides, herbicides, and sequestration were not included in the footprints because their use was limited or data were not available. Table 1 shows a selection of emission factors applied within the model.

Results were expressed in terms of ECM, and the formula for determining ECM $(\mathrm{kg})$ followed Sjaunja et al. (1990):

$$
\begin{gathered}
\mathrm{ECM}=0.25 \times \text { mass of milk }+12.2 \\
\times \text { fat }(\mathrm{kg})+7.7 \times \text { protein }(\mathrm{kg}) .
\end{gathered}
$$

Apportioning of emissions to the meat produced by the systems produces alternative emission totals depending on the method applied. Several publications, including Casey and Holden (2005), quantify these reductions for using varied economic and mass allocation methods; however, in this study no allocation was applied. This was because replacement rates among the systems were similar, culled cows had a range of destinations, and the emissions from those calves that left the system for beef would be attributable to the farms that spend up to 12 mo raising them.

Farm Nutrient Balances. When considering agri-environmental sustainability, $\mathrm{N}$ and $\mathrm{P}$ balances are key indicators (Amon et al., 2011). Quantification of farmgate surpluses of $\mathrm{N}$ and $\mathrm{P}$ is a widely used method that provides an indication of the longer term risks of nutrient losses to the natural environment by leaching and volatilization (Jarvis and Aarts, 2000). A nutrient balance can be described as a measure of the inputs and outputs within a system, where a nutrient surplus is the difference between the input and output of each nutrient.

Absence of an international legal framework designed to account for $\mathrm{N}$ and $\mathrm{P}$ losses results in a lack of common standards and methodologies (Amon et al., 2011). After reviewing available methodologies and their data requirements, a farm $\mathrm{N}$ balance and farm $\mathrm{P}$ balance were calculated for each of the 4 groups annually. Farm balances were a broad indicator, similar to the Organisation for Economic Co-operation and Development's gross balance, with the only difference being that the balance applied here included imports of bedding, which can be significant (Amon et al., 2011). Although it is recognized that soil $\mathrm{N}$ and $\mathrm{P}$ balances are more representative of changes of nutrient storage within the soil and hence provide a more accurate indication of losses to the aquatic environment, the data required for these balances require estimations associated with greater ambiguity than the farm balances used here (Figure 1).

For each herd, the variables required for calculation of $\mathrm{N}$ and $\mathrm{P}$ balances were taken from the database where

Table 1. Emission factors and equations applied within the SAC Carbon Calculator v3.11 (SAC, 2001) to determine the carbon footprints of milk production systems

\begin{tabular}{lll}
\hline Source & Emission factor/equation & Reference \\
\hline Manure $\mathrm{CH}_{4} / \mathrm{cow}$ & $\mathrm{Max} 0.24 \mathrm{~m}^{3}$ of $\mathrm{CH}_{4} / \mathrm{kg}$ of volatile solids & IPCC, 2006 (Chapter 10, page 10.44) \\
Nitrogen fertilizer & $7.11 \mathrm{~kg}$ of $\mathrm{CO}_{2} / \mathrm{kg}$ of N $^{1}$ & Carbon Trust Footprint Expert 3.1 \\
Phosphate fertilizer & $1.85 \mathrm{~kg}$ of $\mathrm{CO}_{2} / \mathrm{kg} \mathrm{of} \mathrm{P}_{2} \mathrm{O}_{5}$ & Carbon Trust Footprint Expert 3.1 \\
Electricity & $0.59 \mathrm{~kg}$ of $\mathrm{CO}_{2} / \mathrm{kWh}$ & DECC, 2011 \\
Diesel & $3.18 \mathrm{~kg}$ of $\mathrm{CO}_{2} / \mathrm{L}$ & DECC, 2011 \\
Compound feed & $341 \mathrm{~kg}$ of $\mathrm{CO}_{2} / \mathrm{t}^{3}$ & Carbon Trust Feeds Database v11(2010) \\
Blended feed $\mathrm{LF}^{4}$ & $154 \mathrm{~kg}$ of $\mathrm{CO}_{2} / \mathrm{t}^{3}$ & Carbon Trust Feeds Database v11(2010) \\
Blended feed $\mathrm{HF}^{4}$ & $198 \mathrm{~kg}$ of $\mathrm{CO}_{2} / \mathrm{t}^{3}$ & Carbon Trust Feeds Database v11(2010) \\
Nitrogen excretion & $0.48 \mathrm{~kg}$ of N $/ 1,000 \mathrm{~kg}$ of cow per day & IPCC, 2006 (Chapter 10, page 10.59) \\
\hline
\end{tabular}

${ }^{1}$ Footprint Expert Product Footprinting Tool [Excel]; Carbon Trust, London, UK.

${ }^{2}$ Derived from typical industry average ingredients estimated by nutritionist Colin Morgan (SAC Consulting, Penicuik, UK; unpublished, 2011).

${ }^{3}$ Emission factors for individual ingredients were sourced from Carbon Trust Feeds Database v11 (2010; Carbon Trust, London, UK).

${ }^{4} \mathrm{LF}=$ low forage diet; $\mathrm{HF}=$ high forage diet. 
Table 2. Nitrogen fixation rates per crop type

\begin{tabular}{lll}
\hline Land use & Fixation rate & Reference \\
\hline Agricultural land & $90 \mathrm{~kg}$ of N/ha per year & Deacon, 2000 \\
Winter wheat & $2.5 \mathrm{~g}$ of N/ha per day for 100 d & Pederson et al., 1978 \\
Pasture (white clover) & $140 \mathrm{~kg}$ of N/ha per year & Leach et al., 2002 \\
Maize (corn) & $4 \mathrm{~g}$ of N/ha per day & Barber et al., 1976 \\
\hline
\end{tabular}

possible, and factors were applied to estimate nutrient inputs and outputs for each system. No manure was imported onto the farm or exported from the farm and no crop products were sold during the experiment.

Farm $N$ Balance. For farm outputs, the average protein content of milk produced was taken from the database and applied to the total yield of each group, with the percentage of $\mathrm{N}$ in $\mathrm{CP}$ taken as $16 \%$. The amount of $\mathrm{N}$ in animals sold $\left(\mathrm{N}_{\text {animal }}\right)$ was calculated based upon the animal weight sold (ARC, 1980):

$$
\mathrm{N}_{\text {animal }}(\mathrm{kg})=0.214 \times \text { live weight }(\mathrm{kg})+0.299 . \quad[2]
$$

Data related to inputs of $\mathrm{N}$ in the form of fertilizer and feed were taken from the database and expressed in $100 \%$ N. The N content of imported feed such as sugar beet pellets was taken directly from feed labels on the farm or from the Feeds Directory (Ewing, 2004). Nitrogen within blended feeds was calculated from results of monthly CP analyses of the feedstuffs. The farm manager provided details of seed application rates $(H$. McLymont, Crichton Research Farm, Dumfries, UK, personal communication). The $\mathrm{N}$ content of seeds for each of the crops, which was taken from the literature (Triboi and Triboi-Blondel, 2001; Yu et al., 2004), and fixation rates, which were applied per crop type, are shown in Table 2.

Rates of atmospheric deposition ( $\mathrm{kg} / \mathrm{ha}$ ) for the Dumfries area were available for each year except 2010 (Defra, 2012). Deposition for 2010 was taken as an average of the 6 yr before 2010. Table 3 outlines descrip- tive statistics for variables used to calculate the farm nitrogen balance.

Farm $\boldsymbol{P}$ Balance. Calculation of farm $\mathrm{P}$ balance was relatively straightforward because fewer variables were included and there was no gaseous loss of $\mathrm{P}$ from manure management systems. Calculating the amount of $\mathrm{P}$ in the inputs and outputs of the farm balance was carried out in the same manner as described for the $\mathrm{N}$ balance. The amount of $\mathrm{P}$ in feed products was taken from the products themselves or the Feeds Directory (Ewing, 2004), and the P in milk was calculated using a factor provided by the Dairy Council (2002). The amount of $\mathrm{P}$ in animals sold $\left(\mathrm{P}_{\text {animal }}\right)$ was calculated from an equation based on the weight of animals sold (ARC, 1980):

$\mathrm{P}_{\text {animal }}(\mathrm{kg})=0.00067 \times$ live weight $(\mathrm{kg})+0.055$.

Table 4 shows descriptive statistics for variables used to calculate the farm $\mathrm{P}$ balance. Phosphate fertilizer was only applied in years 2004 to 2006.

\section{DEA}

Data envelopment analysis is a frequently used method to estimate the efficiency of production systems (Färe et al., 1994). It is presumed, according to traditional microeconomic theory based on the assumption of optimizing behavior, that producers optimize from a technical perspective by not wasting resources. This means that they operate somewhere on the boundary,

Table 3. Descriptive statistics for variables for each milk production system within farm nitrogen balance 2004-2010

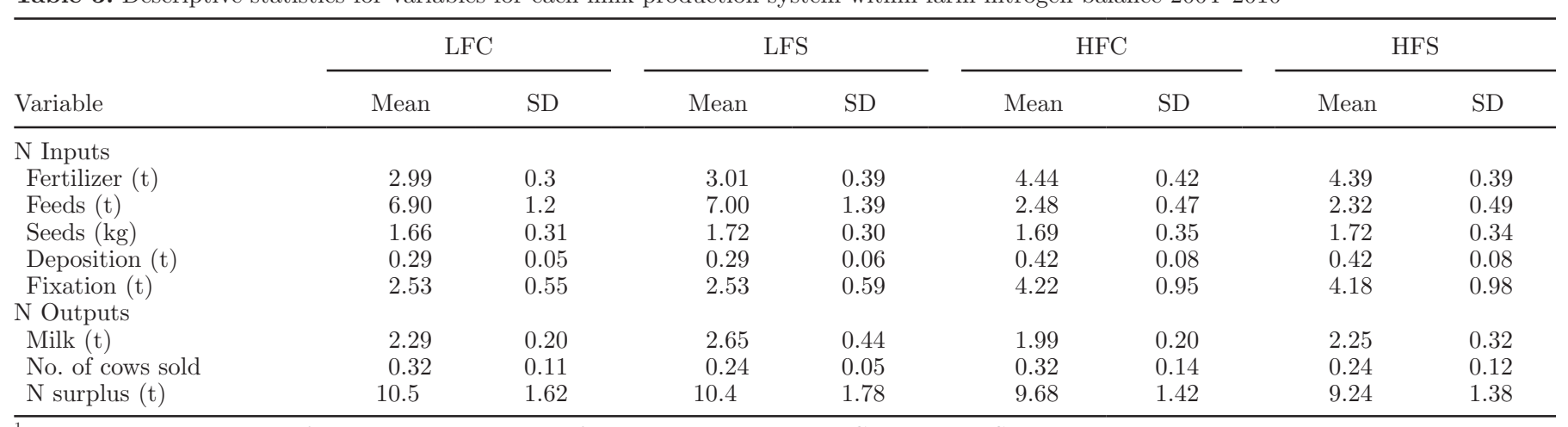

${ }^{1}$ Feed systems: $\mathrm{HF}=$ high forage system, $\mathrm{LF}=$ low forage system; genotype: $\mathrm{C}=$ control, $\mathrm{S}=$ select. 
Table 4. Descriptive statistics for variables for each milk production system within farm phosphate balance $2004-2010^{1}$

\begin{tabular}{|c|c|c|c|c|c|c|c|c|}
\hline \multirow[b]{2}{*}{ Variable } & \multicolumn{2}{|c|}{ LFC } & \multicolumn{2}{|c|}{ LFS } & \multicolumn{2}{|c|}{$\mathrm{HFC}$} & \multicolumn{2}{|c|}{ HFS } \\
\hline & Mean & $\mathrm{SD}^{2}$ & Mean & $\mathrm{SD}$ & Mean & $\mathrm{SD}$ & Mean & $\mathrm{SD}$ \\
\hline \multicolumn{9}{|l|}{ P Input } \\
\hline Fertilizer $(\mathrm{kg})$ & 15.9 & 26.2 & 15.1 & 23.8 & 23.7 & 40.9 & 23.4 & 39.9 \\
\hline Feeds $(\mathrm{t})$ & 1.65 & 0.23 & 1.61 & 0.23 & 1.05 & 0.23 & 0.94 & 0.23 \\
\hline \multicolumn{9}{|l|}{ P Output } \\
\hline Milk (t) & 0.42 & 0.047 & 0.46 & 0.077 & 0.36 & 0.036 & 0.39 & 0.054 \\
\hline Cows sold $(\mathrm{kg})$ & 99.1 & 35.2 & 74.6 & 16.4 & 101.6 & 43.6 & 75.6 & 36.1 \\
\hline $\mathrm{P}$ surplus $(\mathrm{t})$ & 1.26 & 0.17 & 1.21 & 0.15 & 0.72 & 0.15 & 0.62 & 0.14 \\
\hline
\end{tabular}

${ }^{1}$ Feed systems: $\mathrm{HF}=$ high forage system, $\mathrm{LF}=$ low forage system; genotype: $\mathrm{C}=$ control, $\mathrm{S}=$ select.

rather than on the interior, of their production possibility sets. The production possibility set is the set of all nonnegative outputs of goods and services that can be produced using the economy's available factor inputs. The output combinations on the frontier of this set correspond to the Pareto-efficient allocation of factor inputs; that is, the allocation at which it is not possible, given the total factor endowment, to increase the production of one good without decreasing the production of some other good. For different reasons, not all producers succeed in solving the optimization problem in all circumstances. That is why it is important to have a way of analyzing the degree to which producers fail to optimize and the extent of the deviations from technical and economic efficiency (Färe et al., 1994). Several studies have applied DEA to measure the efficiency of dairy farms (Bravo-Ureta and Reiger, 1991; Barnes et al., 2011; Shortall and Barnes, 2013).

Production processes generate 2 major types of outputs: desirable outputs (e.g., milk) and undesirable outputs (e.g., pollutants associated with agricultural emissions from dairy farms). Desirable outputs are considered as strongly disposable; that is, it is always possible to reduce the production of a desirable output without increasing costs. On the other hand, undesir-

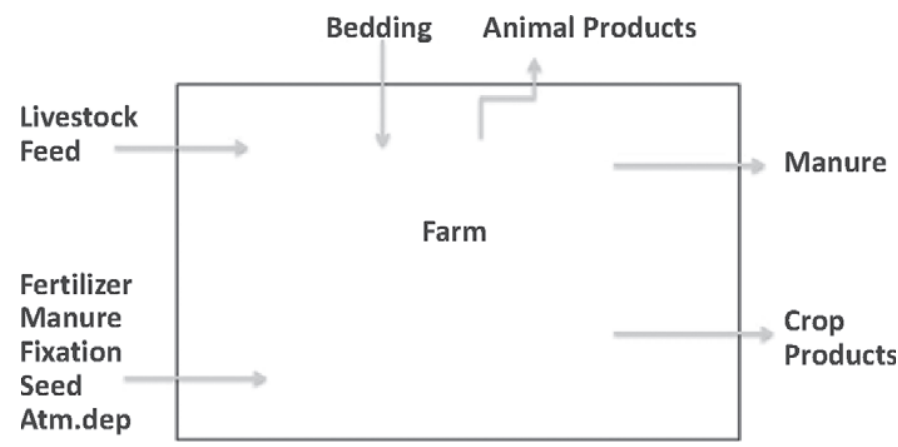

Figure 1. Constituents of a farm $\mathrm{N}$ balance. Atm. Dep. = atmospheric deposition. Source: Amon et al. (2011). (C) European Union, 2011. Reproduced with permission. able outputs are weakly disposable; that is, it is not possible to reduce the production of an undesirable output without reducing the production of a desirable output or increasing the use of an input.

The extension of traditional efficiency analysis to account for undesirable outputs began with Pitman (1983) and has since been further developed along different lines. The basic idea is the estimation of efficiency measures that allow for the asymmetric treatment of desirable and undesirable outputs. Traditional DEA models have been adjusted by considering not only inputs and desirable outputs, but also the third type of factors - the pollutants or undesirable outputs. Färe et al. (1996) introduced the use of an activity analysis model based on the division of overall efficiency into productive efficiency and environmental efficiency. Piot-Lepetit et al. (1995) present information about DEA for identification of agricultural input adjustment which might result in improved technical efficiency and at the same time reduced environmental impacts. Tyteca (1996) investigated the possibilities of obtaining environmental performance indicators from an approach that would be analogous to that classically used to quantify output, input, or overall productive efficiency. He introduced alternative DEA models that differ in their complexity level and in the way in which they account for the 3 categories of factors (desirable outputs, inputs, and undesirable outputs). Various data envelopment techniques for environmental efficiency measurement have been presented in the literature (Tyteca, 1996; Kuosmanen and Kortelainen, 2005; Kortelainen, 2008).

We used 2 DEA models: the undesirable outputoriented model (UO) and the normalized undesirable output-oriented (NUO) model (Tyteca, 1996).

The UO model is as follows: minimize

$$
T(T \leq 1)
$$

subject to 


$$
\begin{gathered}
\sum_{k=1}^{K} \mathbf{Z}^{k} v_{m}^{k} \geq v_{m}^{0} \\
\sum_{k=1}^{K} \mathbf{Z}^{k} w_{j}^{k}=T w_{j}^{0} \\
\sum_{k=1}^{K} \mathbf{Z}^{k} x_{n}^{k} \leq x_{n}^{0}, n=1, \ldots, N, \\
\mathbf{Z}^{k} \geq 0
\end{gathered}
$$

where $m, n$, and $j$ are the numbers of desirable outputs, inputs, and undesirable outputs, taking values from 1 to $M, 1$ to $N$, and 1 to $J$, respectively; $k$ is the number of observations (producers, time periods, or in our case, dairy systems by year and treatment), taking values from 1 to $K ; v_{m}^{0}, w_{j}^{0}, x_{n}^{0}$ are desirable outputs, undesirable outputs, and inputs, respectively. In case of observation 0 , observation $0 \in\{1, \ldots, K\}$ takes values from 1 to $K$, successively. Variable $T$ represents the standardized indicator of environmental performance; $\mathbf{Z}$ is a vector that denotes the intensity levels at which each of the $K$ observations are (or might be) conducted; $\mathbf{Z}$ is a vector that enables shrinking or expanding individual observed activities, for the purpose of constructing unobserved but nonetheless feasible activities. It provides weights that facilitate the construction of the linear segments of the piecewise linear boundary of the technology.

The model shows one key difference to the classical DEA formulation; namely, that instead of minimizing a ratio of inputs to outputs or maximizing a ratio of outputs to inputs, it minimizes a ratio of undesirable outputs to a weighted sum of desirable outputs and inputs. Thus, the undesirable outputs are considered as peculiar outputs that one tries to minimize with respect to the other factors of production (inputs and desirable outputs; Tyteca, 1996):

minimize

$$
h_{0}=\frac{\sum_{j=1}^{J} c_{j} w_{j}^{0}}{\sum_{m=1}^{M} a_{m} v_{m}^{0}-\sum_{n=1}^{N} b_{n} x_{n}^{0}}
$$

where $h_{0}$ represents the standardized indicator of environmental performance; and $a_{m}, b_{n}$, and $c_{j}$ denote intensity levels, subject to

$$
\begin{gathered}
\frac{\sum_{j=1}^{J} c_{j} w_{j}^{k}}{\sum_{m=1}^{M} a_{m} v_{m}^{k}-\sum_{n=1}^{N} b_{n} x_{n}^{k}} \geq 1 \\
a_{m}, b_{n} \geq 0
\end{gathered}
$$

The problem assumes constant returns to scale; that is, in pollution terms, for efficient dairy systems, namely those showing a value of $T=1$, a given increase in desirable outputs or inputs, or both, would result in a proportional increase in undesirable outputs (Färe, 1992). The problem can be modified to assume varying returns to scale by the addition of the constraint presented in Equation [6] (Lovell, 1993; Yaisawarng and Klein, 1994; Tyteca, 1996):

$$
\sum_{k=1}^{K} \mathbf{Z}^{k}=1
$$

One limitation of this approach is that all undesirable outputs have to vary according to the same proportion because of the uniqueness of the $T$ factor affecting all undesirable output components (Tyteca, 1996).

The NUO model is as follows: minimize

$$
T(T \leq 1)
$$

subject to

$$
\begin{gathered}
\sum_{k=1}^{K} \mathbf{Z}^{k} v_{m}^{k} \geq v_{m}^{0} \\
\sum_{k=1}^{K} \mathbf{Z}^{k} w_{j}^{k}=T w_{j}^{0}, j=1, \ldots, J, \\
\mathbf{Z}^{k} \geq 0 ; k=1, \ldots, K .
\end{gathered}
$$

Compared with the UO model, the NUO model is a simplified version of the DEA formulation in the sense that it no longer accounts for inputs. In the case of only one desirable output, we simply consider weighted sums of undesirable outputs scaled by the desirable output (Tyteca, 1996).

Estimating the models allowed us to assess the effect of inputs by comparing efficiency values and rankings between models. Four models were estimated: 2 UO mod- 
els, where undesirable outputs were (1) GHG emissions $\left(\mathrm{CO}_{2}\right.$ equivalent; $\left.\mathbf{C O}_{2} \mathbf{e}\right)$ and $\mathrm{N}$ surplus $\left(\mathbf{U O} \mathbf{C O}_{2}, \mathbf{N}\right)$, and (2) $\mathrm{CO}_{2}, \mathbf{N}$, and $\mathrm{P}$ surplus ( $\mathbf{U O} \mathbf{C O}_{2}, \mathbf{N}, \mathbf{P}$ ); and 2 NUO models, where undesirable outputs were (1) $\mathrm{CO}_{2}$ and $\mathrm{N}\left(\mathbf{N U O} \mathbf{C O}_{2}, \mathbf{N}\right)$, and $(2) \mathrm{CO}_{2}, \mathrm{~N}$, and $\mathrm{P}(\mathbf{N U O}$ $\left.\mathbf{C O}_{2}, \mathbf{N}, \mathbf{P}\right)$. Milk production was the desirable output in all 4 models. Inputs included in the $2 \mathrm{UO}$ models were land, nitrogen fertilizers, feed (home-grown and purchased), and cows (milking cows and young stock).

In building the relative environmental efficiency measure, we use the DEA endogenous weighting scheme (Farrell, 1957; Charnes et al., 1978; Tyteca, 1996); that is, instead of a priori specified (subjective) weights based on potential environmental damage, this technique endogenously selects the weights that present every evaluated decision-making unit (DMU) in the most favorable light.

Applying weights to environmental factors is an approach used by researchers dealing with pollutant inventories; however, it is not evident that deriving individual weights would properly quantify the combined effect of all pollutants in all possible site-specific contexts, as their effects are likely to vary as a function of the geographical site considered (Milford et al., 1989), and a lack of consensus exists in this regard (Tyteca, 1996). Moreover, it is even less evident that the combined effects of pollutants would result in linear interactions.

As an alternative to the weights based on impact on environment, cost coefficients that reflect the damage caused by the effluents to the environment could be used if and when available. This procedure has some recognized difficulties; namely, although there are some estimates of the damage costs associated with GHG and for carbon value at the UK level (Price et al., 2007; DECC, 2009), marginal damage cost values for the other pollutants (e.g., $\mathrm{NH}_{3}, \mathrm{~N}$ leaching or $\mathrm{P}$ ) are even more contested due to the uncertainties involved (Eory et al., 2013). Part of the reason is that the other pollutants are more localized than GHG, so their marginal damage value is highly dependent on (and varies with) the region where the emissions occur (based on the baseline pollutant load, the threshold for pollution effects, and what is being damaged in the specific area). Area-specific valuation of each pollutant's damage costs is rarely available. Another reason is that $\mathrm{N}$ and $\mathrm{P}$ surpluses are indicators of the $\mathrm{N}$ and $\mathrm{P}$ excess; however, no information is available on the different forms of these pollutants. For instance, $\mathrm{N}_{2} \mathrm{O}, \mathrm{NO}, \mathrm{NO}_{2}$, $\mathrm{NH}_{3}$, and $\mathrm{NO}_{3}^{-}$are pollutants, whereas $\mathrm{N}_{2}$ is harmless (Sutton et al., 2011); they have different effects on the environment and therefore should be assigned different weights. Without this information, marginal damage costs and, implicitly, correct weights cannot be assigned to these undesirable outputs.

Data envelopment analysis is a method that does not require the specification of a priori weights on the variables, thus it is ideally suited for our case. We estimated the models using the General Algebraic Modeling System (GAMS 22.8); GAMS programs for the DEA models are available on request from the authors.

We used DEA to account for temporal aspects; that is, not only to compare the dairy systems among themselves, but to quantify changes in environmental efficiency over time. The models consider each of the 4 systems (LFC, LFS, HFC, and HFS) as divided into 7 independent DMU (for each year between 2004 and 2010), which results in a set of 28 DMU (a similar approach was used by Färe et al., 1996 and Ball et al., 1994). Thus, the best-practice production frontier is composed of systems that were efficient in any of the $7 \mathrm{yr}$. The analysis allows us to provide a measurement of improvement (or deterioration) in environmental efficiency for each system over time.

\section{One-Way ANOVA}

We used a one-way ANOVA procedure to identify significant differences between efficiency scores by year and dairy system type. We tested for mean differences using post hoc tests [least significant difference (LSD) test for equal variances and Tamhane test for unequal variances].

\section{Tobit Model}

We use the Tobit model (Tobin, 1958) to estimate the effects of variables related to the physical condition of animals within the milking herd on the environmental efficiency of dairy systems. The Tobit model has been used in this context frequently in the literature (Coelli et al., 2002; Hansson, 2008; Manevska-Tasevska et al., 2011) because the dependent variable takes values varying from zero to unity.

The model is presented in Equations [8] and [9] (Greene, 2003):

$$
\begin{gathered}
y_{i}= \begin{cases}y_{i}^{*} & \text { if } y_{i}^{*}>0 \\
0 & \text { if } y_{i}^{*} \leq 0\end{cases} \\
y_{i}^{*}=\boldsymbol{\beta} x_{i}+u_{i}, u_{i} \sim N\left(0, \sigma^{2}\right),
\end{gathered}
$$

where $y_{i}^{*}$ is a latent dependent variable; $x_{i}$ is the independent variable; $\boldsymbol{\beta}$ is a parameter (vector) that deter- 
Table 5. Mean $\mathrm{N}$ and $\mathrm{P}$ surpluses and greenhouse gas (GHG) emissions per liter of ECM for each milk production system $2004-2010^{1}$

\begin{tabular}{llllll}
\hline Output & Type & LFC & LFS & HFC & HFS \\
\hline Nitrogen & Surplus/L (kg) & 0.023 & 0.021 & 0.025 & 0.022 \\
Phosphorus & Surplus/L (kg) & 0.0028 & 0.0025 & 0.0018 & 0.0015 \\
GHG & Direct $\mathrm{kg}$ of CO & 0.09 & 0.09 & 0.08 \\
& Indirect $\mathrm{kg} \mathrm{of} \mathrm{CO}$ & 0.23 & 0.20 & 0.25 & 0.21 \\
& kg of $\mathrm{CO}_{2} \mathrm{e}$ from methane & & \\
& $\mathrm{kg}$ of $\mathrm{CO}_{2} \mathrm{e}$ from nitrous oxide & 0.56 & 0.49 & 0.74 & 0.63 \\
Total GHG & $\mathrm{kg}$ of $\mathrm{CO}_{2} \mathrm{e} / \mathrm{kg}$ of ECM & 1.04 & 0.13 & 0.25 & 0.22 \\
\hline
\end{tabular}

${ }^{1}$ Feed systems: $\mathrm{HF}=$ high forage system, $\mathrm{LF}=$ low forage system; genotype: $\mathrm{C}=$ control, $\mathrm{S}=$ select.

${ }^{2} \mathrm{CO}_{2} \mathrm{e}=\mathrm{CO}_{2}$ equivalents

mines the relationship between the independent variable $x_{i}$ and the latent variable $y_{i}^{*} ; u_{i}$ is a normally distributed error term.

Quasi-maximum likelihood (Huber/White) for robust standard errors was used to correct for heteroscedasticity. The dependent variable was the environmental efficiency score, and the independent variables included in the model were incidence of udder health disorders and BCS (a herd management tool that ensures cows are in the correct condition for each stage in their cycle and if not, dietary changes can be made). Udder disorders include mastitis, Escherichia coli, blockages, and reduced milk. The Tobit model was estimated with econometric software EViews7.1 (http://www.eviews.com).

\section{RESULTS}

\section{Carbon Footprint and Nutrient Surplus Results}

Surplus nutrients were greater in the LF groups, which mainly stems from quantities of $\mathrm{N}$ and $\mathrm{P}$ in imported feeds. However, we did not observe substantial differences between groups when comparing nutrient surpluses per kilogram of ECM because the LF groups generally produced considerably more milk per year. Phosphate surpluses showed greater variation between feed groups because of less $\mathrm{P}$ input in the HF diet. Output of $\mathrm{P}$ was greater in the control groups because a higher conception rate increased the number of animals sold from these groups. Table 5 provides descriptive statistics of GHG estimates and nutrient balance calculations averaged from 2004 to 2010 . Annual results for each pollutant type per feeding system and genetic merit represent undesirable outputs that should be minimized.

On average, the LFS system produced less GHG per kilogram of ECM. This group produced less manurerelated methane and nitrous gases because of the continuous housing management. The LF diet generated a greater amount of indirect $\mathrm{CO}_{2}$ emissions from purchased feeds than the HF group, although the HF system required more land and fertilizer, which resulted in a similar per-liter indirect $\mathrm{CO}_{2}$ totals. The $\mathrm{HF}$ herd emitted more enteric methane per liter of milk than the LF herd because of their diet composition. Table 6 shows descriptive statistics for inputs, desirable outputs, and undesirable outputs, subsequently used as variables in the DEA models.

\section{DEA Results}

Results of the DEA indicated that the HF systems were more volatile than the LF systems, which could reflect the influence of crop production and forage quality on the HF diet (Table 7). The GAMS listing of weights (values of z-variables) for all iterations in each model are presented in Tables S1 to S4 in the online data supplement (http://dx.doi.org/10.3168/jds.20136911).

The highest to lowest efficiency systems were LFS > HFS > LFC > HFC when scores of each system in each model were averaged. For HF systems, the best and worst years coincided, which highlights the dependency of the HF system on annual weather patterns. In the case of LF systems, the best and worst years differed, which could be due to annual variation in culling rates between $\mathrm{S}$ and $\mathrm{C}$ cows. When considering associations between the environmental efficiency and productivity, it is clear that high environmental efficiency is not confined to higher production systems. Figure 2 shows average efficiency scores plotted against annual milk output for each system and indicates that the most efficient systems were spread across a production range $\left(368-602 \mathrm{~m}^{3} / \mathrm{yr}\right)$. This was the case with all models and agrees with results from other published work (Iribarren et al., 2011). High production systems have consistently high efficiency; however, in some years, low production systems also have high efficiency.

We tested for mean differences between environmental efficiency scores by year and dairy system types using a one-way ANOVA. Results of testing differences in mean efficiency scores by year are presented in Tables 8 and 9 and Figure 3. 
Table 6. Descriptive statistics of variables for each milk production system 2004-2010 1

\begin{tabular}{|c|c|c|c|c|c|c|c|c|}
\hline Variable & \multicolumn{2}{|c|}{ LFC } & \multicolumn{2}{|c|}{ LFS } & \multicolumn{2}{|c|}{$\mathrm{HFC}$} & \multicolumn{2}{|c|}{ HFS } \\
\hline \multicolumn{9}{|l|}{ Inputs } \\
\hline $\mathrm{N}$ fertilizer $(\mathrm{t})$ & 3.0 & 0.3 & 3.0 & 0.4 & 4.4 & 0.4 & 4.4 & 0.4 \\
\hline Grown feed $(\mathrm{t})$ & 712.0 & 100.1 & 718.5 & 109.4 & 717.0 & 79.1 & 700.4 & 76.4 \\
\hline Bought feed $(\mathrm{t})$ & 461.5 & 52.5 & 452.3 & 56.8 & 306.9 & 33.1 & 284.3 & 28.5 \\
\hline \multicolumn{9}{|l|}{ Desirable outputs } \\
\hline $\operatorname{ECM}(\mathrm{t})$ & 441.8 & 45.2 & 500.0 & 87.0 & 392.3 & 34.9 & 436.2 & 58.0 \\
\hline \multicolumn{9}{|l|}{ Undesirable outputs } \\
\hline GHG $\mathrm{CO}_{2} \mathrm{e}^{2}(\mathrm{t})$ & 460.0 & 56.4 & 451.8 & 65.7 & 517.8 & 59.9 & 497.9 & 66.1 \\
\hline $\mathrm{N}$ Surplus $(\mathrm{t})$ & 10.5 & 1.6 & 10.4 & 1.8 & 9.7 & 1.4 & 9.2 & 1.4 \\
\hline P Surplus (t) & 1.3 & 0.17 & 1.2 & 0.15 & 0.7 & 0.15 & 0.6 & 0.14 \\
\hline
\end{tabular}

${ }^{1}$ Feed systems: $\mathrm{HF}=$ high forage system, $\mathrm{LF}=$ low forage system; genotype: $\mathrm{C}=$ control, $\mathrm{S}=$ select.

${ }^{2}$ Greenhouse gases in $\mathrm{CO}_{2}$ equivalents.

Table 7. Environmental efficiency scores for the models applied to each milk production system from 2004 to 2010

\begin{tabular}{|c|c|c|c|c|}
\hline \multirow[b]{2}{*}{ System/year ${ }^{1}$} & \multicolumn{4}{|c|}{ Model $^{2}$} \\
\hline & $\mathrm{NUO} \mathrm{CO}_{2}, \mathrm{~N}, \mathrm{P}$ & $\mathrm{NUO} \mathrm{CO}_{2}, \mathrm{~N}$ & $\mathrm{UO} \mathrm{CO}_{2}, \mathrm{~N}, \mathrm{P}$ & $\mathrm{UO} \mathrm{CO}_{2}, \mathrm{~N}$ \\
\hline \multicolumn{5}{|l|}{$\overline{L F C}$} \\
\hline 2004 & 0.915 & 0.904 & 0.915 & 0.912 \\
\hline 2005 & 1 & 0.833 & 1 & 0.833 \\
\hline 2006 & 0.876 & 0.833 & 0.88 & 0.854 \\
\hline 2007 & 0.88 & 0.862 & 0.88 & 0.862 \\
\hline 2008 & 0.902 & 0.866 & 0.902 & 0.866 \\
\hline 2009 & 0.922 & 0.849 & 1 & 0.856 \\
\hline 2010 & 0.8 & 0.791 & 0.8 & 0.791 \\
\hline \multicolumn{5}{|l|}{ LFS } \\
\hline 2004 & 0.996 & 0.986 & 1 & 1 \\
\hline 2005 & 1 & 0.895 & 1 & 0.896 \\
\hline 2006 & 1 & 0.966 & 1 & 1 \\
\hline 2007 & 1 & 1 & 1 & 1 \\
\hline 2008 & 1 & 1 & 1 & 1 \\
\hline 2009 & 1 & 0.987 & 1 & 1 \\
\hline 2010 & 1 & 1 & 1 & 1 \\
\hline \multicolumn{5}{|l|}{$\mathrm{HFC}$} \\
\hline 2004 & 0.82 & 0.804 & 0.82 & 0.804 \\
\hline 2005 & 0.861 & 0.858 & 0.861 & 0.858 \\
\hline 2006 & 1 & 1 & 1 & 1 \\
\hline 2007 & 0.826 & 0.676 & 0.826 & 0.676 \\
\hline 2008 & 0.723 & 0.688 & 0.723 & 0.688 \\
\hline 2009 & 0.828 & 0.828 & 0.828 & 0.828 \\
\hline 2010 & 0.731 & 0.724 & 0.731 & 0.724 \\
\hline \multicolumn{5}{|l|}{ HFS } \\
\hline 2004 & 1 & 0.973 & 1 & 1 \\
\hline 2005 & 0.992 & 0.979 & 1 & 1 \\
\hline 2006 & 1 & 1 & 1 & 1 \\
\hline 2007 & 1 & 0.759 & 1 & 0.826 \\
\hline 2008 & 0.868 & 0.824 & 1 & 1 \\
\hline 2009 & 0.895 & 0.89 & 0.905 & 0.902 \\
\hline 2010 & 0.986 & 0.97 & 1 & 1 \\
\hline
\end{tabular}

${ }^{1}$ Feed systems: $\mathrm{HF}=$ high forage system, $\mathrm{LF}=$ low forage system; genotype: $\mathrm{C}=$ control, $\mathrm{S}=$ select.

${ }^{2} \mathrm{NUO} \mathrm{CO}_{2}, \mathrm{~N}, \mathrm{P}=$ normalized undesirable output-oriented (NUO) model with undesirable outputs $\mathrm{CO}_{2}, \mathrm{~N}$, and $\mathrm{P}$; $\mathrm{NUO} \mathrm{CO}_{2}, \mathrm{~N}=\mathrm{NUO}$ model with undesirable outputs $\mathrm{CO}_{2}$ and $\mathrm{N}$; $\mathrm{UO} \mathrm{CO}_{2}, \mathrm{~N}, \mathrm{P}=$ undesirable outputoriented (UO) model with undesirable outputs $\mathrm{CO}_{2}$ and $\mathrm{N}, \mathrm{P} ; \mathrm{UO} \mathrm{CO}_{2}, \mathrm{~N}=\mathrm{UO}$ model with undesirable outputs $\mathrm{CO}_{2}$ and $\mathrm{N}$. 


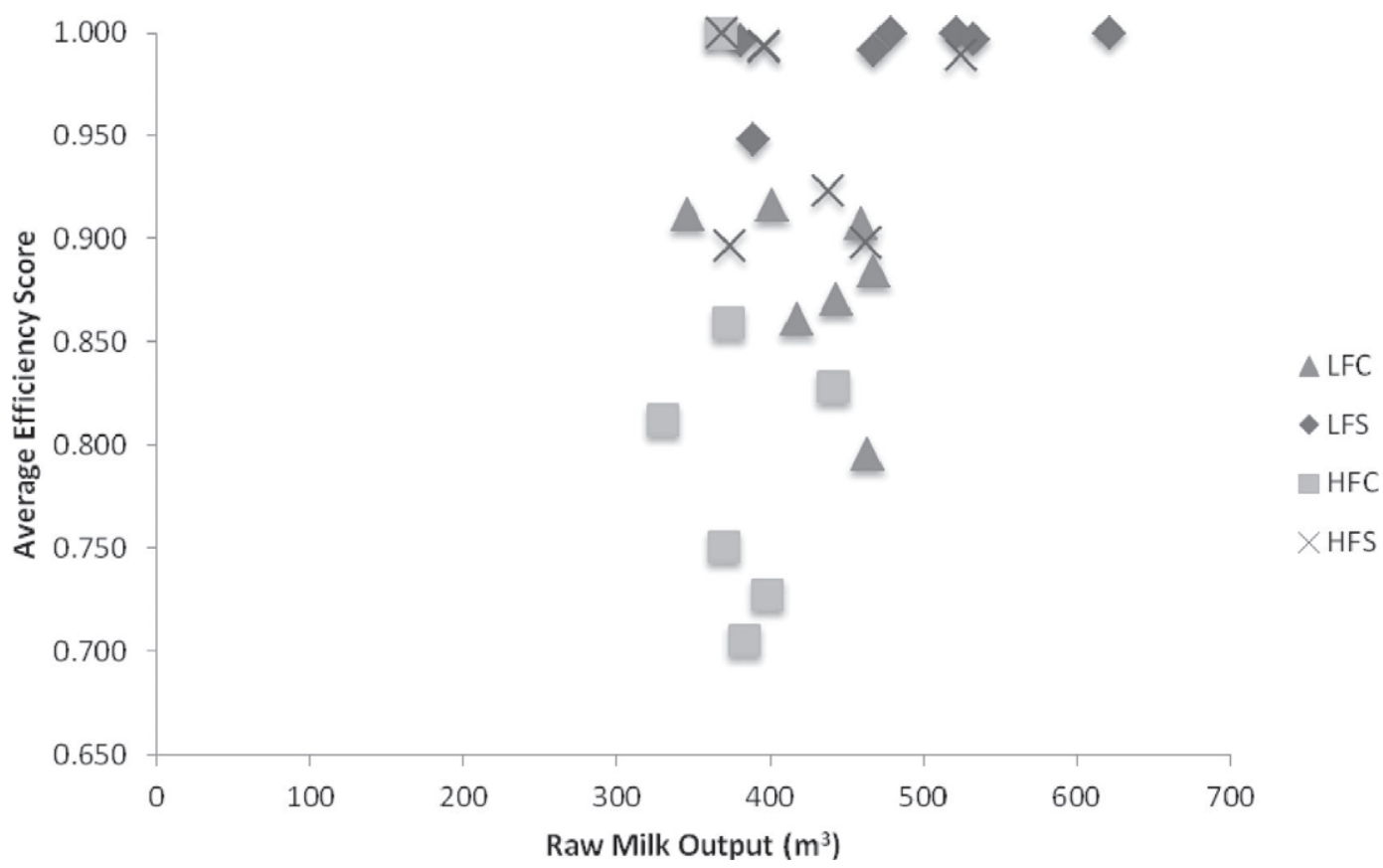

Figure 2. Average of efficiency scores versus raw milk production for each milk production system. Feed systems: HF = high forage system, $\mathrm{LF}=$ low forage system; genotypes: $\mathrm{C}=$ control, $\mathrm{S}=$ select.

The graphs (Figure 3) show equality of variance across groups. Similarly, the Levene statistic (Table 8) did not reject the null hypothesis that the group variances are equal for each model between years. The significance value of the $F$-test in the ANOVA (Table 9 ) was $>0.05$; thus, we cannot reject the hypothesis that average efficiency scores are equal across years (i.e., efficiency scores did not differ significantly between years). Additionally, we compared differences year-byyear with post hoc tests (LSD test for equal variances) and no significant differences were found. Results of the LSD test for equal variances are available online (http://dx.doi.org/10.3168/jds.2013-6911).
Results of testing differences in mean efficiency scores by system are presented in Tables 10, 11, and 12 and Figure 4. The graphs (Figure 4) show inequality of variance across groups. Similarly, the Levene statistic (Table 10) rejects the null hypothesis that the system group variances are equal for each model. The significance value of the $F$-test in the ANOVA (Table 11) was $<0.05$; thus, we reject the hypothesis that average efficiency scores were equal across years (i.e., average efficiency scores differed significantly between systems). To see precisely where the significant differences originated, we ran post hoc tests (Tamhane test for unequal variances; Table 12).

Table 8. Differences between environmental efficiency scores by year: Test of homogeneity of variances for models $^{1}$

\begin{tabular}{lcccc}
\hline Model $^{2}$ & $\begin{array}{c}\text { Levene } \\
\text { statistic }\end{array}$ & df1 & df2 & Significance \\
\hline NUO CO $\mathrm{CO}_{2}, \mathrm{~N}, \mathrm{P}$ & 1.305 & 6 & 21 & 0.298 \\
$\mathrm{NUO} \mathrm{CO}, \mathrm{N}$ & 1.214 & 6 & 21 & 0.338 \\
$\mathrm{UO} \mathrm{CO}$ & $\mathrm{N}, \mathrm{P}$ & 6 & 21 & 0.215 \\
$\mathrm{UO} \mathrm{CO}$ & 1.535 & 6 & 21 & 0.360 \\
\hline
\end{tabular}

${ }^{1}$ df1 represents the degrees of freedom between groups [df1 = y - 1, where y equals the number of groups (i.e., 7 years)]; df2 represents the degrees of freedom within groups [df2 $=\mathrm{k}-\mathrm{y}$, where $\mathrm{k}$ equals the number of values in the set (i.e., $28 \mathrm{DMU})]$.

${ }^{2} \mathrm{NUO} \mathrm{CO}_{2}, \mathrm{~N}, \mathrm{P}=$ normalized undesirable output-oriented (NUO) model with undesirable outputs $\mathrm{CO}_{2}, \mathrm{~N}$, and P; NUO $\mathrm{CO}_{2}, \mathrm{~N}=\mathrm{NUO}$ model with undesirable outputs $\mathrm{CO}_{2}$ and $\mathrm{N}$; $\mathrm{UO} \mathrm{CO}_{2}, \mathrm{~N}, \mathrm{P}=$ undesirable outputoriented (UO) model with undesirable outputs $\mathrm{CO}_{2}$ and $\mathrm{N}, \mathrm{P} ; \mathrm{UO} \mathrm{CO}_{2}, \mathrm{~N}=\mathrm{UO}$ model with undesirable outputs $\mathrm{CO}_{2}$ and $\mathrm{N}$. 
Table 9. Analysis of variance for models

\begin{tabular}{|c|c|c|c|c|c|c|}
\hline Model $^{1}$ & & $\begin{array}{l}\text { Sum of } \\
\text { squares }\end{array}$ & df & $\begin{array}{l}\text { Mean } \\
\text { square }\end{array}$ & $F$-statistic & Significance \\
\hline \multirow[t]{3}{*}{$\mathrm{NUO} \mathrm{CO}_{2}, \mathrm{~N}, \mathrm{P}$} & Between groups & 0.033 & 6 & 0.006 & \multirow[t]{3}{*}{0.654} & \multirow[t]{3}{*}{0.687} \\
\hline & Within groups & 0.179 & 21 & 0.009 & & \\
\hline & Total & 0.213 & 27 & & & \\
\hline \multirow[t]{3}{*}{$\mathrm{NUO} \mathrm{CO}_{2}, \mathrm{~N}$} & Between groups & 0.043 & 6 & 0.007 & \multirow[t]{3}{*}{0.657} & \multirow[t]{3}{*}{0.685} \\
\hline & Within groups & 0.229 & 21 & 0.011 & & \\
\hline & Total & 0.273 & 27 & & & \\
\hline \multirow[t]{3}{*}{$\mathrm{UO} \mathrm{CO}_{2}, \mathrm{~N}, \mathrm{P}$} & Between groups & 0.023 & 6 & 0.004 & \multirow[t]{3}{*}{0.397} & \multirow[t]{3}{*}{0.872} \\
\hline & Within groups & 0.200 & 21 & 0.010 & & \\
\hline & Total & 0.222 & 27 & & & \\
\hline \multirow{3}{*}{$\mathrm{UO} \mathrm{CO}_{2}, \mathrm{~N}$} & Between groups & 0.036 & 6 & 0.006 & \multirow[t]{3}{*}{0.492} & \multirow[t]{3}{*}{0.807} \\
\hline & Within groups & 0.255 & 21 & 0.012 & & \\
\hline & Total & 0.291 & 27 & & & \\
\hline
\end{tabular}

${ }^{1} \mathrm{NUO} \mathrm{CO}_{2}, \mathrm{~N}, \mathrm{P}=$ normalized undesirable output-oriented (NUO) model with undesirable outputs $\mathrm{CO}_{2}, \mathrm{~N}$, and P; NUO $\mathrm{CO}_{2}, \mathrm{~N}=\mathrm{NUO}$ model with undesirable outputs $\mathrm{CO}_{2}$ and $\mathrm{N}$; $\mathrm{UO} \mathrm{CO}_{2}, \mathrm{~N}, \mathrm{P}=$ undesirable outputoriented (UO) model with undesirable outputs $\mathrm{CO}_{2}$ and $\mathrm{N}, \mathrm{P} ; \mathrm{UO} \mathrm{CO}_{2}, \mathrm{~N}=\mathrm{UO}$ model with undesirable outputs $\mathrm{CO}_{2}$ and $\mathrm{N}$.

The results showed significant differences between systems in each model. The $\mathrm{UO} \mathrm{CO}_{2}, \mathrm{~N}$ model presented the largest number of significant differences: between LFC and LFS, between HFC and HFS, between LFC and HFS, and between LFS and HFC. The NUO $\mathrm{CO}_{2}, \mathrm{~N}, \mathrm{P}$ model presented significant differences between LFC and LFS, between HFC and HFS, and between LFS and HFC. The NUO $\mathrm{CO}_{2}, \mathrm{~N}$ model showed significant differences between LFC and LFS, and between LFS and HFC. The UO $\mathrm{CO}_{2}, \mathrm{~N}, \mathrm{P}$ model presented significant differences between LFS and HFC, and between HFC and HFS.

The correspondence between the 2 DEA models (UO and NUO) was estimated using Spearman rank correlation and Kendall's Tau tests. According to the Spearman rank correlation test, the UO and NUO models were highly correlated, with a Spearman coefficient equal to 0.897 for NUO $\mathrm{CO}_{2}, \mathrm{~N}, \mathrm{P}$ and $\mathrm{UO} \mathrm{CO}_{2}, \mathrm{~N}, \mathrm{P}$ models, and 0.897 for the NUO $\mathrm{CO}_{2}, \mathrm{~N}$ and $\mathrm{UO} \mathrm{CO}_{2}, \mathrm{~N}$ models (correlations significant at the 0.01 level; 2-tailed). According to Kendall's Tau test (based on the number of concordant and discordant pairs of observations), the UO and NUO models showed a correlation coefficient of 0.850 for the NUO $\mathrm{CO}_{2}, \mathrm{~N}, \mathrm{P}$ and $\mathrm{UO} \mathrm{CO}_{2}, \mathrm{~N}, \mathrm{P}$ models, and 0.842 for the NUO $\mathrm{CO}_{2}, \mathrm{~N}$ and $\mathrm{UO} \mathrm{CO}_{2}, \mathrm{~N}$ models (correlations significant at the 0.01 level; 2-tailed). The 2 statistical tests proved that there were more differences between scores than between rankings obtained from the 2 types of models. Additionally, we ran the DEA models for each of the undesirable outputs $\left(\mathrm{CO}_{2}\right.$, $\mathrm{N}$, and $\mathrm{P}$ ). According to the Spearman rank correlation test, the UO and NUO models were significantly correlated in all cases, with a Spearman coefficient equal to 0.858 for the $\mathrm{NUO} \mathrm{CO}_{2}$ and $\mathrm{UO} \mathrm{CO}_{2}$ models, 0.968 for the NUO N and UO N models (correlations significant at the 0.01 level; 2-tailed), and 0.396 for the NUO P and UO P models (correlation significant at the 0.05 level; 2-tailed). According to Kendall's Tau test, the UO and NUO models were significantly correlated in all cases, showing a correlation coefficient of 0.735 for NUO $\mathrm{CO}_{2}$ and UO $\mathrm{CO}_{2}$ models, 0.905 for the NUO N and UO N models (correlations significant at the 0.01 level; 2-tailed), and 0.321 for the NUO P and UO P models (correlation significant at the 0.05 level; 2 -tailed). The 2 statistical tests confirmed that there were more differences between scores than between rankings obtained from the 2 types of models in all cases; that is, combined undesirable outputs and each undesirable output considered separately.

\section{Tobit Model Results}

Both of the independent variables (incidence of udder disorder and BCS) had a statistically significant effect on environmental efficiency scores in all models. These results highlight the lower incidence of udder health issues in the HF (grazed) herds. Body condition scores among the $\mathrm{S}$ cows tended to be lower, because they were more likely to give up their body condition to the production of milk. Results are presented in Table 13.

\section{DISCUSSION}

The UK dairy sector can be depicted by a diversity of management practices that, in recent years, have relinquished traditional all-summer grazing in favor of import-based feeding and year-round housing. Implementing efficiency improvements across a range of management types requires system-specific strategies. Western Europe and the United Kingdom are already among the most economically and carbon-efficient producers of milk in Europe and the world (O'Mara, 2011; DairyCo, 2012). 
Table 10. Differences between environmental efficiency scores by system: Test of homogeneity of variances for models ${ }^{1}$

\begin{tabular}{|c|c|c|c|c|}
\hline $\mathrm{Model}^{2}$ & $\begin{array}{l}\text { Levene } \\
\text { statistic }\end{array}$ & df1 & df2 & Significance \\
\hline $\mathrm{NUO} \mathrm{CO}_{2}, \mathrm{~N}, \mathrm{P}$ & 2.628 & 3 & 24 & 0.073 \\
\hline $\mathrm{NUO} \mathrm{CO}_{2}, \mathrm{~N}$ & 4.202 & 3 & 24 & 0.016 \\
\hline $\mathrm{UO} \mathrm{CO}_{2}, \mathrm{~N}, \mathrm{P}$ & 3.014 & 3 & 24 & 0.050 \\
\hline $\mathrm{UO} \mathrm{CO}_{2}, \mathrm{~N}$ & 3.511 & 3 & 24 & 0.031 \\
\hline
\end{tabular}

${ }^{1}$ df1 represents the degrees of freedom between groups [df1 = y - 1, where y equals the number of groups (i.e., 4 milk production systems)]; df2 represents the degrees of freedom within groups [df2 $=\mathrm{k}-\mathrm{y}$, where $\mathrm{k}$ equals the number of values in the set (i.e., $28 \mathrm{DMU})]$.

${ }^{2} \mathrm{NUO} \mathrm{CO}_{2}, \mathrm{~N}, \mathrm{P}=$ normalized undesirable output-oriented (NUO) model with undesirable outputs $\mathrm{CO}_{2}, \mathrm{~N}$, and $\mathrm{P}$; NUO $\mathrm{CO}_{2}, \mathrm{~N}=\mathrm{NUO}$ model with undesirable outputs $\mathrm{CO}_{2}$ and $\mathrm{N}$; $\mathrm{UO} \mathrm{CO}_{2}, \mathrm{~N}, \mathrm{P}=$ undesirable outputoriented (UO) model with undesirable outputs $\mathrm{CO}_{2}$ and $\mathrm{N}, \mathrm{P} ; \mathrm{UO} \mathrm{CO}_{2}, \mathrm{~N}=\mathrm{UO}$ model with undesirable outputs $\mathrm{CO}_{2}$ and $\mathrm{N}$.

a)

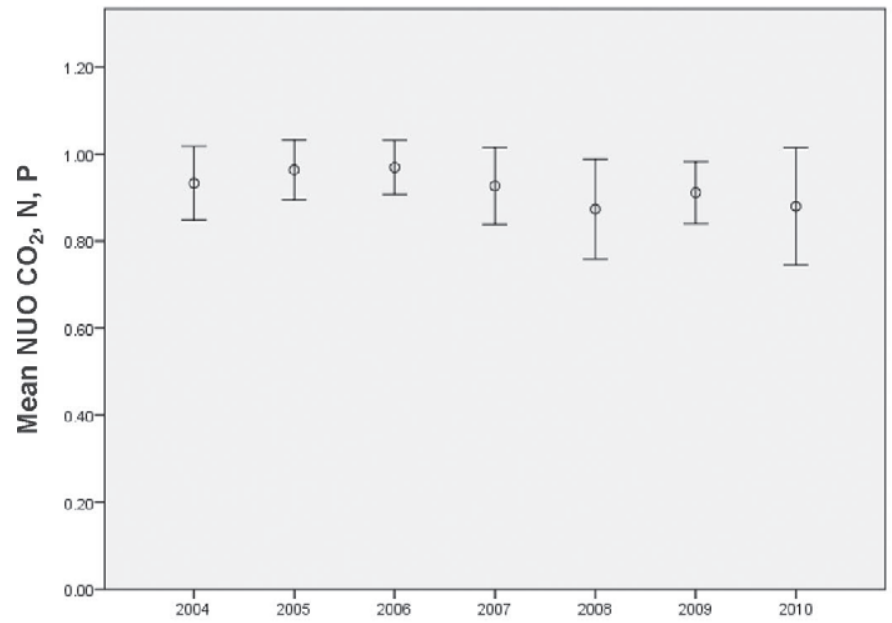

b)

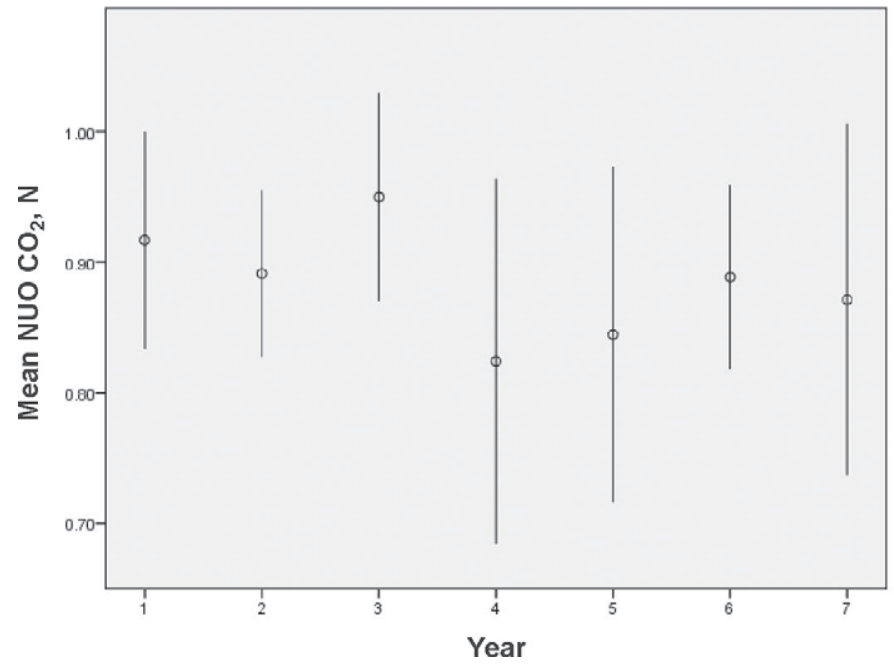

c)

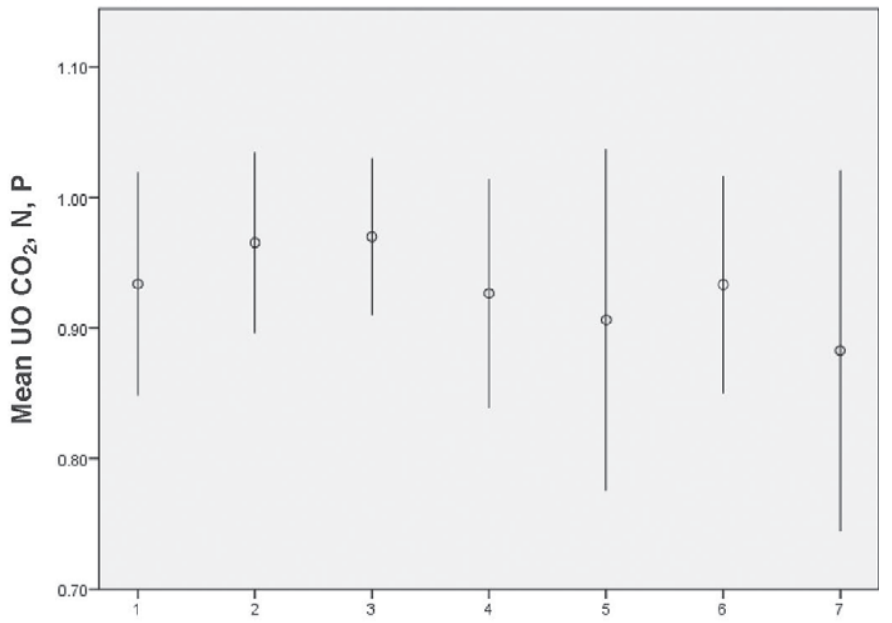

d)

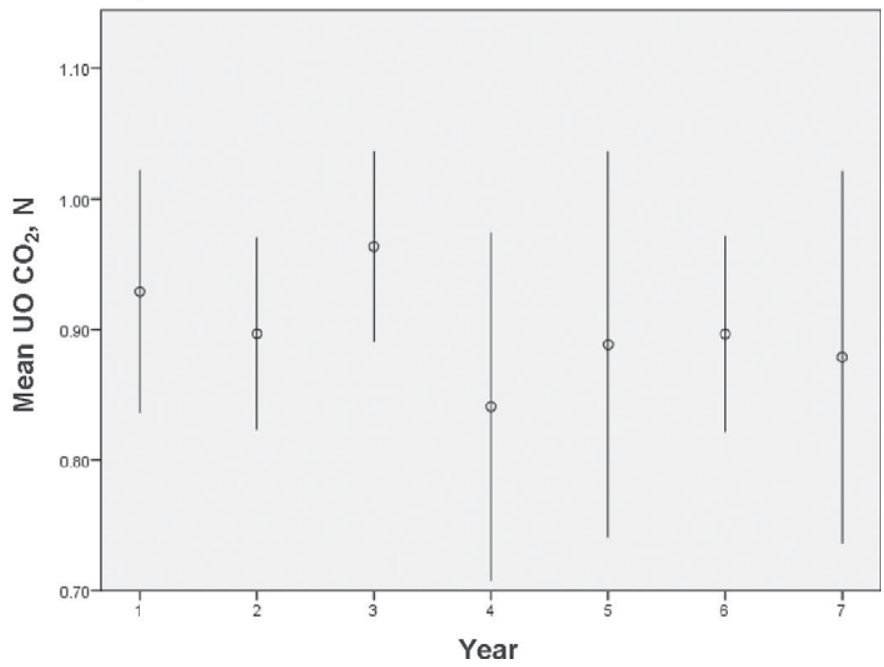

Figure 3. Graphing means and standard errors to test homogeneity of variances of environmental efficiency scores by year for models: (a) NUO $\mathrm{CO}_{2}, \mathrm{~N}, \mathrm{P}=$ normalized undesirable output-oriented (NUO) model with undesirable outputs $\mathrm{CO}_{2}, \mathrm{~N}$, and $\mathrm{P} ;(\mathrm{b}) \mathrm{NUO} \mathrm{CO}_{2}, \mathrm{~N}=\mathrm{NUO}$ model with undesirable outputs $\mathrm{CO}_{2}$ and $\mathrm{N}$; (c) $\mathrm{UO} \mathrm{CO}_{2}, \mathrm{~N}, \mathrm{P}=$ undesirable output-oriented (UO) model with undesirable outputs $\mathrm{CO}_{2}, \mathrm{~N}$, and $\mathrm{P}$; (d) $\mathrm{UO} \mathrm{CO}_{2}, \mathrm{~N}=\mathrm{UO}$ model with undesirable outputs $\mathrm{CO}_{2}$ and $\mathrm{N}$. 
Table 11. Analysis of variance for models

\begin{tabular}{|c|c|c|c|c|c|c|}
\hline Model $^{1}$ & & $\begin{array}{l}\text { Sum of } \\
\text { squares }\end{array}$ & df & $\begin{array}{l}\text { Mean } \\
\text { square }\end{array}$ & $F$-statistic & Significance \\
\hline \multirow[t]{3}{*}{$\mathrm{NUO} \mathrm{CO}_{2}, \mathrm{~N}, \mathrm{P}$} & Between groups & 0.121 & 3 & 0.040 & \multirow[t]{3}{*}{10.481} & \multirow[t]{3}{*}{0.000} \\
\hline & Within groups & 0.092 & 24 & 0.004 & & \\
\hline & Total & 0.213 & 27 & & & \\
\hline \multirow[t]{3}{*}{$\mathrm{NUO} \mathrm{CO}_{2}, \mathrm{~N}$} & Between groups & 0.128 & 3 & 0.043 & \multirow[t]{3}{*}{7.067} & \multirow[t]{3}{*}{0.001} \\
\hline & Within groups & 0.145 & 24 & 0.006 & & \\
\hline & Total & 0.273 & 27 & & & \\
\hline \multirow[t]{3}{*}{$\mathrm{UO} \mathrm{CO}_{2}, \mathrm{~N}, \mathrm{P}$} & Between groups & 0.133 & 3 & 0.044 & \multirow[t]{3}{*}{11.975} & \multirow[t]{3}{*}{0.000} \\
\hline & Within groups & 0.089 & 24 & 0.004 & & \\
\hline & Total & 0.222 & 27 & & & \\
\hline \multirow[t]{3}{*}{$\mathrm{UO} \mathrm{CO}_{2}, \mathrm{~N}$} & Between groups & 0.167 & 3 & 0.056 & \multirow[t]{3}{*}{10.714} & \multirow[t]{3}{*}{0.000} \\
\hline & Within groups & 0.124 & 24 & 0.005 & & \\
\hline & Total & 0.291 & 27 & & & \\
\hline
\end{tabular}

${ }^{1} \mathrm{NUO} \mathrm{CO}_{2}, \mathrm{~N}, \mathrm{P}=$ normalized undesirable output-oriented (NUO) model with undesirable outputs $\mathrm{CO}_{2}, \mathrm{~N}$, and P; NUO $\mathrm{CO}_{2}, \mathrm{~N}=\mathrm{NUO}$ model with undesirable outputs $\mathrm{CO}_{2}$ and $\mathrm{N}$; $\mathrm{UO} \mathrm{CO}_{2}, \mathrm{~N}, \mathrm{P}=$ undesirable outputoriented (UO) model with undesirable outputs $\mathrm{CO}_{2}$ and $\mathrm{N}, \mathrm{P} ; \mathrm{UO} \mathrm{CO}_{2}, \mathrm{~N}=\mathrm{UO}$ model with undesirable outputs $\mathrm{CO}_{2}$ and $\mathrm{N}$.

The methods applied in this study evaluated undesirable outputs and compared relative efficiencies of 2 divergent dairy management systems to understand the differences between overall environmental performances. Langhill total farmgate emissions per system were comparable with a recent survey that reported an average of $1.31 \mathrm{~kg}$ of $\mathrm{CO}_{2} \mathrm{e}$ per $\mathrm{kg}$ of ECM (DairyCo, 2012) and are consistent with a Scottish survey that reported $1.37 \mathrm{~kg}$ of $\mathrm{CO}_{2} \mathrm{e} / \mathrm{L}$ (Sheane et al., 2010). Even though these emissions per kilogram of ECM are much lower than the global average of $2.7 \mathrm{~kg}$ of $\mathrm{CO}_{2}(\mathrm{FAO}$, 2010), the potential exists for lowering GHG emissions and nutrient surpluses within each system. The LF (housed) system was more carbon efficient, primarily because less manure-related emissions were generated; however, emissions from purchased feeds could offset this should the yield differences not be so great. System footprints could be reduced by introducing feeds with lower emission factors, such as by-products, or by introducing new technologies, such as installing an anaerobic digester. Lowering nutrient surpluses is limited by inefficiencies within the process of converting feed into milk (Dewhurst and Thomas, 1992); however, opportunities for reduction exist within each system. Nitrogen surplus could be reduced by introducing lower-protein forages in the diet, increasing milk yield per cow, reducing fertilizer application rates, and improving manure management (Roberts et al., 2007). Cost-effective approaches to reduce $\mathrm{P}$ surplus can be understood by whole-farm nutrient system analysis, and strategies include those tailored to land and crop management. Optimization of $\mathrm{P}$ in the diet has the potential to reduce surplus; however, this can lead to increased feed costs (Nousiainen et al., 2011). Nutrient losses resulting from slurry application can be controlled by regulations such as the EU Nitrates Directive (European Council, 1991), which currently focuses on N. However, the introduction of the EU Water Framework Directive (European Parliament and Council, 2000), which regulates aquatic systems as a whole, may lead to the development of combined nutrient manure management plans.

Ranking efficiency scores and comparing DEA model types showed little discrepancy between the majority of system years, as most DMU were similarly ranked. However, exceptions were noted: HFS 2007 ranked considerably more favorably in models that contained $\mathrm{P}$ as a pollutant, because this system year generated the least amount of surplus compared with all groups in all years and performed comparatively well with regard to other pollutants; LFC 2005 also performed better when $\mathrm{P}$ was included in the DEA model because of a comparatively higher milk yield. These instances highlight the benefits of considering more than one type of pollutant as well as more than one type of model.

Results of the Tamhane test showed significant differences between the efficiency scores of the 4 dairy management systems, which arose from genetics or feed type factors. Across all DEA models, significance between system efficiency scores arose from genetic differences more often than feed system differences. These results also highlight an interaction between the dairy management systems, the choice of pollutants, and the type of DEA model implemented. The NUO models did not incorporate the effects of input use, and significant differences found here resulted mainly from genetics. When looking at UO models, an equal number of system differences caused by genetics were found to occur; however, there were greater instances of feed type differences. These results emphasize that resource inputs play an important role in the measurement of overall environmental performance of these dairy systems. This is a potentially important finding 
Table 12. Tamhane test for unequal variances for models for each milk production system ${ }^{1}$

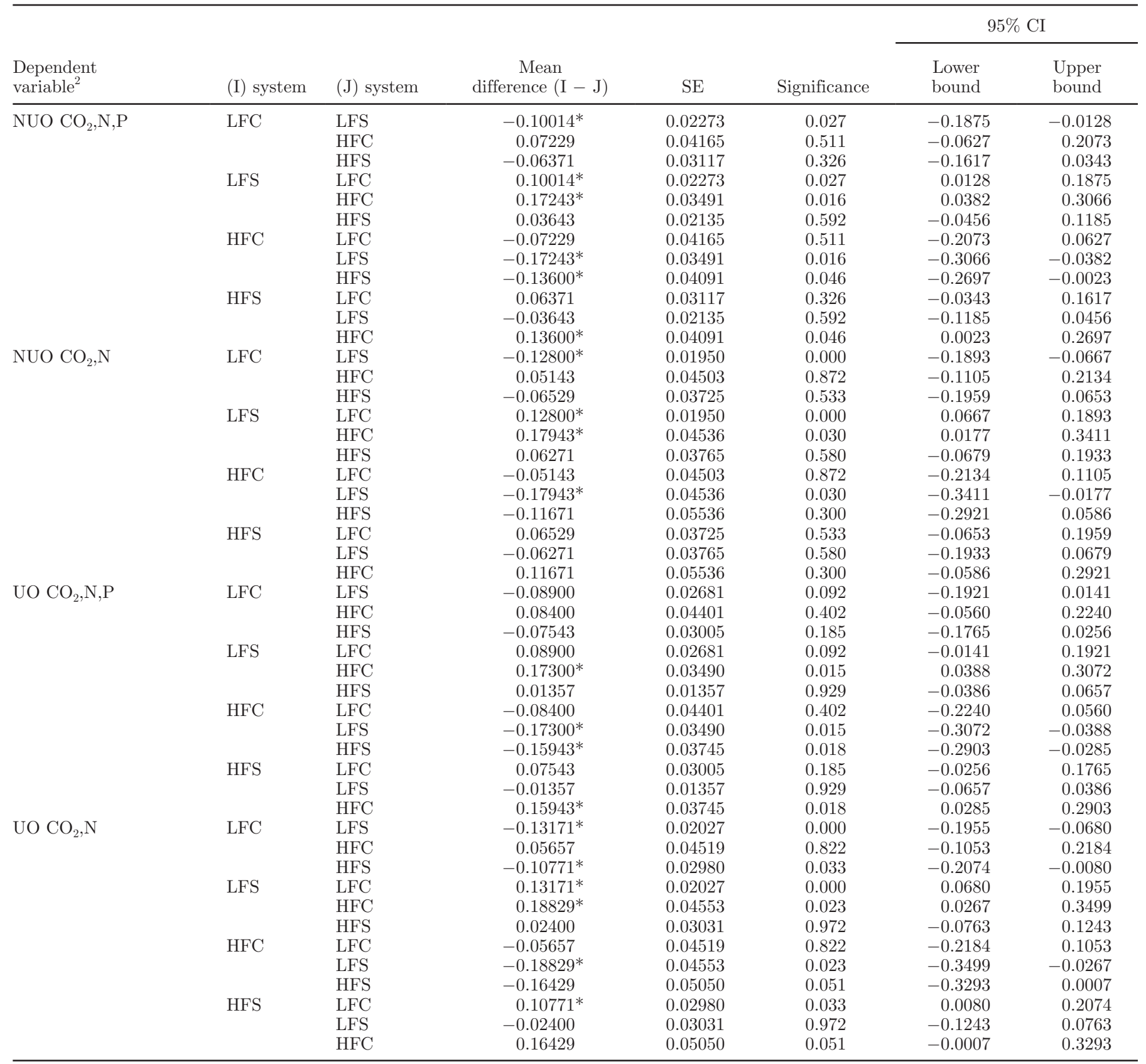

${ }^{1}$ Feed systems: $\mathrm{HF}=$ high forage system, $\mathrm{LF}=$ low forage system; genotype: $\mathrm{C}=$ control, $\mathrm{S}=$ select.

${ }^{2} \mathrm{NUO} \mathrm{CO}_{2}, \mathrm{~N}, \mathrm{P}=$ normalized undesirable output-oriented (NUO) model with undesirable outputs $\mathrm{CO}_{2}, \mathrm{~N}$, and $\mathrm{P} ; \mathrm{NUO} \mathrm{CO}_{2}, \mathrm{~N}=\mathrm{NUO}$ model with undesirable outputs $\mathrm{CO}_{2}$ and $\mathrm{N} ; \mathrm{UO} \mathrm{CO}_{2}, \mathrm{~N}, \mathrm{P}=$ undesirable output-oriented (UO) model with undesirable outputs $\mathrm{CO}_{2}$ and $\mathrm{N}$, P; UO $\mathrm{CO}_{2}, \mathrm{~N}=\mathrm{UO}$ model with undesirable outputs $\mathrm{CO}_{2}$ and $\mathrm{N}$.

$* P<0.05$.

because earlier work suggested that high-genetic-merit cows did not lose their advantage on low-input feeding regimens; that is, there was no $\mathrm{G} \times \mathrm{E}$ based on gross energetic efficiency (Veerkamp et al., 1994). However, this study suggests that the situation is less clear when environmental efficiency is considered. It could be ex- pected that no significant differences in efficiency score between years were found to occur, because the diets should have been as constant as possible to conform within the Langhill systems experiment.

This study found that udder health disorders and BCS had a significant effect on environmental effi- 
a)

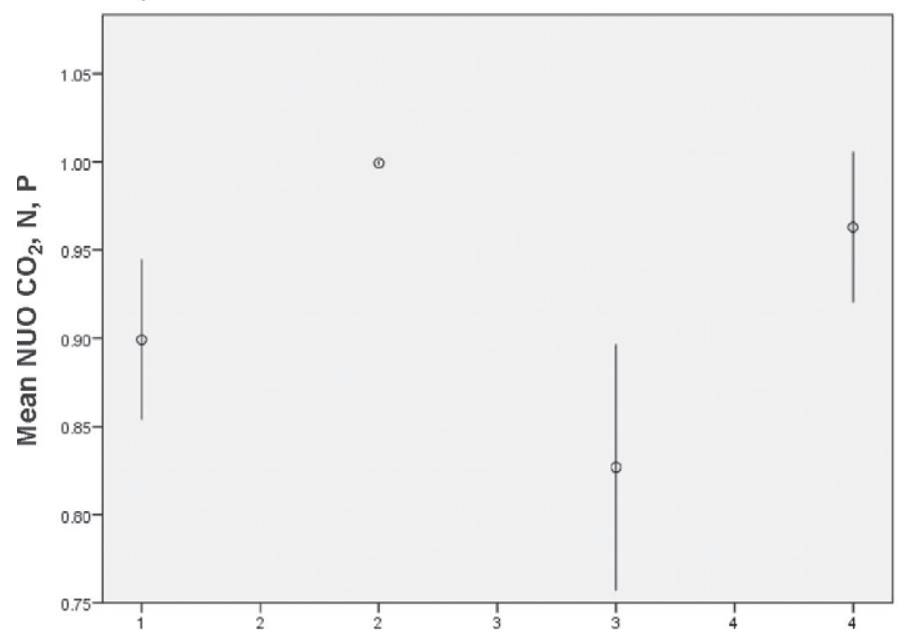

b)

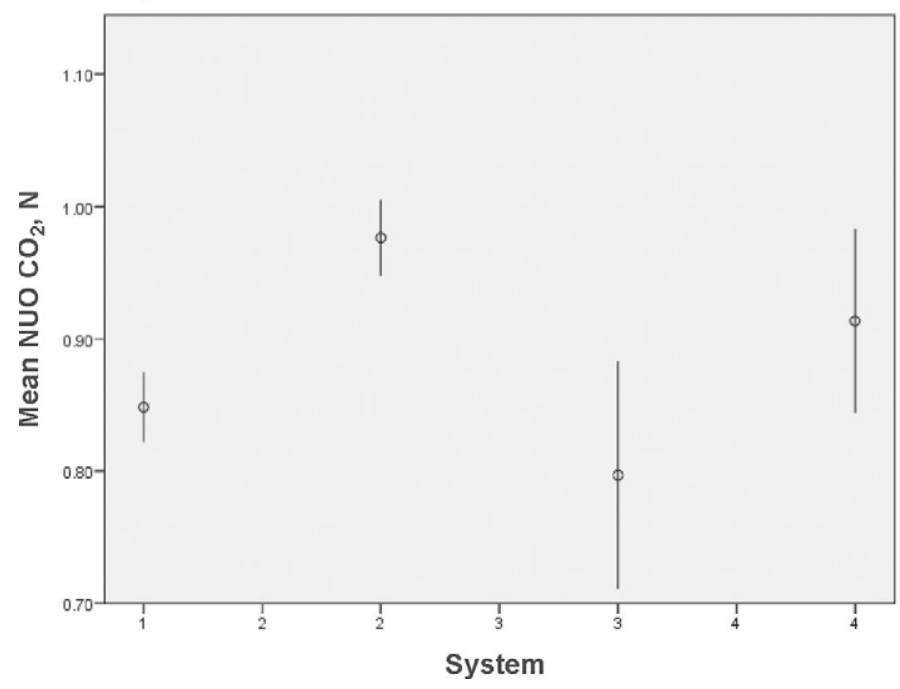

c)

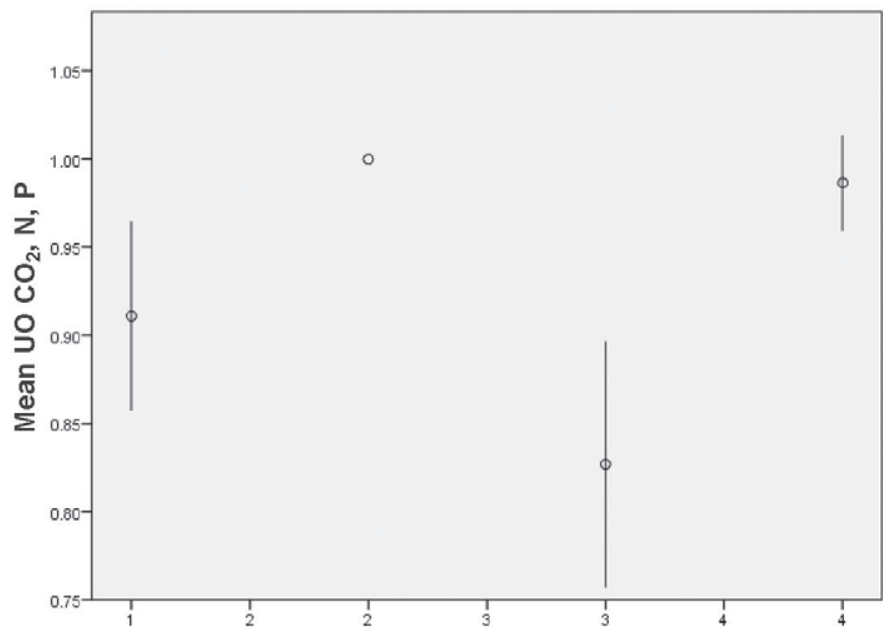

d)

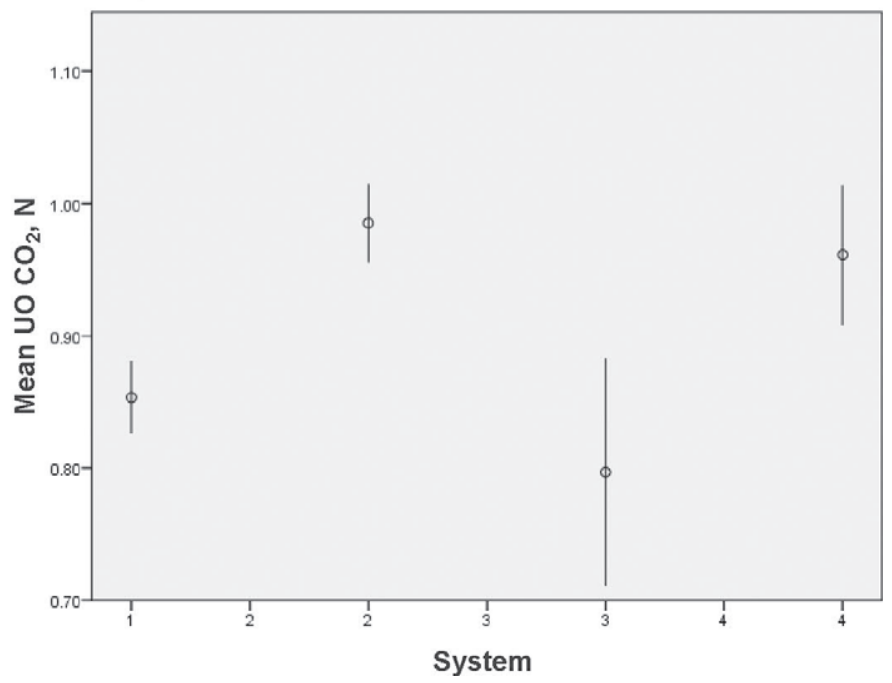

Figure 4. Graphing means and standard errors to test homogeneity of variances of environmental efficiency scores by system for models: (a) $\mathrm{NUO} \mathrm{CO}_{2}, \mathrm{~N}, \mathrm{P}=$ normalized undesirable output-oriented (NUO) model with undesirable outputs $\mathrm{CO}_{2}, \mathrm{~N}$, and $\mathrm{P}$; (b) $\mathrm{NUO} \mathrm{CO}_{2}, \mathrm{~N}=\mathrm{NUO}$ model with undesirable outputs $\mathrm{CO}_{2}$ and $\mathrm{N}$; (c) $\mathrm{UO} \mathrm{CO}_{2}, \mathrm{~N}, \mathrm{P}=$ undesirable output-oriented (UO) model with undesirable outputs $\mathrm{CO}_{2}$, $\mathrm{N}$, and $\mathrm{P} ;$ (d) $\mathrm{UO} \mathrm{CO}_{2}, \mathrm{~N}=\mathrm{UO}$ model with undesirable outputs $\mathrm{CO}_{2}$ and $\mathrm{N}$.

ciency scores, which indicates the importance of animal health within milk production systems. Analyzing the effect of various factors on efficiency is a frequently used approach in the literature (Barnes et al., 2011; Manevska-Tasevska et al., 2011).

Opportunities exist for UK dairy farmers to successfully compete in a global industry, because grasslands, primarily in the west of Britain, receive ample rainfall and the growing season is sufficient. Moreover, 2015 should herald a new era because output will no longer be restricted by milk quotas introduced in 1984 under the European Common Agricultural Policy. Regeneration of milk production should be carried out in a sustainable manner with an emphasis on increasing efficiency and lowering undesirable outputs.
It could be argued that research farms such as Langhill are generally more efficient in terms of resource use; they perform better in terms of average yields and, as such, could act as references for environmental policy. A changing climate may provide further opportunities in some parts of the United Kingdom as the growing season could be extended if predictions of warmer and wetter summers are realized, and UK dairy farmers could capitalize on natural resources as other regions may not have such opportunities.

The policy implications of this analysis would be enhanced if, instead of considering the best practice frontier, the DEA models used a frontier reflecting environmental quality targets. Thus, dairy systems would be ranked with respect to each other and with 
Table 13. Tobit model results (coefficients, robust SE, z-statistic test, and probabilities)

\begin{tabular}{|c|c|c|c|c|}
\hline Model and trait ${ }^{1}$ & Coefficient & $\mathrm{SE}^{2}$ & z-Statistic & Probability \\
\hline \multicolumn{5}{|l|}{$\mathrm{NUO} \mathrm{CO}_{2}, \mathrm{~N}, \mathrm{P}$} \\
\hline BCS & 0.384373 & 0.021984 & 17.48418 & $0.0000^{* *}$ \\
\hline Incidence of udder disorder & 0.019139 & 0.007428 & 2.576629 & $0.0100^{* *}$ \\
\hline \multicolumn{5}{|l|}{$\mathrm{NUO} \mathrm{CO}_{2}, \mathrm{~N}$} \\
\hline $\mathrm{BCS}$ & 0.377125 & 0.018913 & 19.94027 & $0.0000^{* *}$ \\
\hline Incidence of udder disorder & 0.010193 & 0.004387 & 2.323409 & $0.0202^{*}$ \\
\hline \multicolumn{5}{|l|}{$\mathrm{UO} \mathrm{CO}_{2}, \mathrm{~N}, \mathrm{P}$} \\
\hline BCS & 0.377291 & 0.028120 & 13.41728 & $0.0000^{* *}$ \\
\hline Incidence of udder disorder & 0.034911 & 0.010827 & 3.224353 & $0.0013^{* *}$ \\
\hline \multicolumn{5}{|l|}{$\mathrm{UO} \mathrm{CO}_{2}, \mathrm{~N}$} \\
\hline $\mathrm{BCS}$ & 0.372700 & 0.028083 & 13.27129 & $0.0000^{* *}$ \\
\hline Incidence of udder disorder & 0.021610 & 0.007911 & 2.731487 & $0.0063^{* *}$ \\
\hline \multicolumn{5}{|c|}{$\begin{array}{l}{ }^{1} \mathrm{NUO} \mathrm{CO}_{2}, \mathrm{~N}, \mathrm{P}=\text { normalized undesirable output-oriented }(\mathrm{NUO}) \text { model with undesirable outputs } \mathrm{CO}_{2} \text {, } \\
\text { and } \mathrm{P} \text {; } \mathrm{NUO} \mathrm{CO}_{2}, \mathrm{~N}=\mathrm{NUO} \text { model with undesirable outputs } \mathrm{CO}_{2} \text { and } \mathrm{N} ; \mathrm{UO} \mathrm{CO}_{2}, \mathrm{~N}, \mathrm{P}=\text { undesirable outp } \\
\text { oriented (UO) model with undesirable outputs } \mathrm{CO}_{2} \text { and } \mathrm{N}, \mathrm{P} ; \mathrm{UO} \mathrm{CO}_{2}, \mathrm{~N}=\mathrm{UO} \text { model with undesira } \\
\text { outputs } \mathrm{CO}_{2} \text { and } \mathrm{N} \text {. }\end{array}$} \\
\hline
\end{tabular}

respect to a hypothetical system based on low carbon policy goals. If measures to mitigate GHG emissions are adopted alongside strategies for nutrient surplus reduction annually at a system level, then advances in environmental performance could be acknowledged and quantified. Alternatively, or additionally, a comparison between the efficiency of the mitigation measures used could be undertaken (Bosetti and Buchner, 2009). Other opportunities for improvements in the methodology would be to include pesticides within the footprints and water use as additional DEA variables. Indicators for animal welfare and biodiversity could also be included, if data are available.

\section{CONCLUSIONS}

The purpose of this paper was to compare the environmental efficiency of divergent strains of dairy cows within contrasting management systems and investigate any $\mathrm{G} \times \mathrm{E}$ interaction. Although the LFS system was most efficient in the majority of DEA models, cows of the same genetic merit on HFS could be just as efficient. Results indicated no $\mathrm{G} \times \mathrm{E}$ interaction, but do indicate that system efficiency is not limited to high milk production and that lower production systems are shown to be efficient in some years. Inputs play an important role in the measurement of environmental efficiency of dairy systems, and opportunities to reduce undesirable outputs varied dependent upon system type. Thus, mitigation of dairy pollutants should be customized by system. Efficiency scores for the LF groups were less variable from year to year, which reflected the uniformity of purchased concentrate feeds.
Significant differences were found between efficiency scores among the systems, mainly due to genetic rather than feed system differences. Furthermore, herd health was shown to be an important factor. Improving herd health by, for example, targeted health schemes would lead to improved environmental efficiency. Environmental efficiency demands a holistic approach to ensure that all attributes of dairy systems are properly matched to production circumstances and objectives. A focus on high outputs or single indices of technical efficiency alone may not address the multiple challenges food production systems face.

\section{ACKNOWLEDGMENTS}

Scotland's Rural College (SRUC) receives grantin-aid from the Scottish Government. This research was funded by the Scottish Government Rural Affairs and the Environment Portfolio Strategic Research Programme 2011-2016 Theme 4.2 "Low Carbon Rural Economy." For more information, please see http:// www.scotland.gov.uk/Topics/Research/About/EBAR/ StrategicResearch/future-research-strategy/Themes/ ThemesIntro. The authors are grateful to Vera Eory (SRUC, Kings Building, Edinburgh, UK), Stephen Ross (SRUC, Dumfries, UK), and two anonymous reviewers for useful comments.

\section{REFERENCES}

Alvis, D., A. Jackson, and J. Allen. 2012. Can big be beautiful? The relationship between size of unit and sustainability in housed livestock systems, Royal Agricultural Society of England. Accessed Oct. 28, 2012. http://www.appg-agscience.org.uk/linkedfiles/WCFLivestockReportFullOct2012.pdf. 
Amon, B., N. Hutchings, F. Vinther, P. Nielsen, H. Poulsen, S. Kristensen, and S. Pietrzak. 2011. Analysis of methodologies for calculating greenhouse gas and ammonia emissions and nutrient balances, European Commission. Accessed Jan. 23, 2012. http://epp. eurostat.ec.europa.eu/cache/ITY_OFFPUB/KS-RA-11-024/EN/ KS-RA-11-024-EN.PDF

Anderson, S., and S. Gundel. 2011. Evidence of livestock sector impacts on the climate and the wider environment: a brief science review, Global Food and Farming Futures, Workshop Report 5 , The Government Office for Science. Accessed Sep. 8, 2013. http:// www.bis.gov.uk/assets/bispartners/foresight/docs/food-andfarming/workshops/11-609-w5-evidence-livestock-sector-impacton-climate.

ARC. 1980. The Nutrient Requirements of Ruminant Animals. Commonwealth Agricultural Bureau, The Gresham Press, Old Woking, Surrey, UK.

Ball, V. E., C. A. K. Lovell, R. F. Nehring, and A. Somwaru. 1994 Incorporating undesirable outputs into models of production: An application to U.S. agriculture. Cahiers D'economie et Sociologie Rurales 31:59-74.

Barber, L. E., J. D. Tjepkema, S. A. Russell, and H. J. Evans. 1976. Acetylene reduction nitrogen fixation associated with corn inoculated with Spirillum. Appl. Environ. Microbiol. 32:108-113.

Barnes, A. P., K. M. D. Rutherford, F. M. Langford, and M. J. Haskell 2011. The effect of lameness prevalence on technical efficiency at the dairy farm level: An adjusted data envelopment analysis approach. J. Dairy Sci. 94:5449-5457.

Bosetti, V., and B. Buchner. 2009. Data envelopment analysis of different climate policy scenarios. Ecol. Econ. 68:1340-1354.

Bravo-Ureta, B., and L. Reiger. 1991. Dairy farm efficiency measurement using stochastic frontiers and neoclassical duality. Am. J. Agric. Econ. 73:421-428.

Casey, J. W., and N. M. Holden. 2005. Analysis of greenhouse gas emissions from the average Irish milk production system. Agric. Syst. 86:97-114.

Chagunda, M. G. G., D. A. M. Römer, and D. J. Roberts. 2009. Effect of genotype and feeding regime on enteric methane, non-milk nitrogen and performance of dairy cows during the winter feeding period. Livest. Sci. 122:323-332.

Charnes, A., W. W. Cooper, and E. Rhodes. 1978. Measuring the efficiency of decision-making units. Eur. J. Oper. Res. 2:429-444.

Coelli, T., S. Rahman, and C. Thirtle. 2002. Technical, allocative, cost and scale efficiencies in Bangladesh rice cultivation: A nonparametric approach. J. Agric. Econ. 53:607-626.

Dairy Council. 2002. The nutritional composition of dairy products. Accessed Sep. 8, 2013. http://www.milk.co.uk/resources/resource. aspx?intResourceID $=55$.

DairyCo. 2009. Desktop review of greenhouse gas (GHG) emissions. Accessed Sep. 8, 2013. http://www.dairyco.net/library/researchdevelopment/climate-change/desktop-review-of-greenhouse-gases. aspx.

DairyCo. 2011. Datum on-farm data. Accessed Sep. 8, 2013. http:// www.dairyco.net/datum/on-farm-data.aspx.

DairyCo. 2012. Greenhouse gas emissions on British dairy farms: DairyCo carbon footprinting study: Year one. Accessed Sep. 8 2013. http://www.dairyco.org.uk/resources-library/technicalinformation/climate-change/carbon-footprint-report-2012/.

Deacon, J. 2000. The microbial world, the nitrogen cycle and nitrogen fixation. University of Edinburgh. Accessed Sep. 8, 2013. http:// www.biology.ed.ac.uk/archive/jdeacon/microbes/nitrogen.htm.

DECC (Department of Energy and Climate Change). 2009. Carbon Valuation in UK Policy Appraisal: A Revised Approach. Climate Change Economics, DECC, London, UK.

DECC (Department of Energy and Climate Change). 2011. GHG conversion factors for company reporting. Accessed Sep. 9, 2013. http://archive.defra.gov.uk/environment/business/reporting/pdf/ 110707-guidelines-ghg-conversion-factors.pdf.

Defra (Department for Environment, Food and Rural Affairs). 2008. The environmental impact of livestock production: Review of research and literature. Accessed Sep. 8, 2013. http://archive.defra. gov.uk/foodfarm/farmanimal/documents/envimpacts-livestock. pdf.

Defra (Department for Environment, Food and Rural Affairs). 2011 Agricultural statistics and climate change. 1st ed. Accessed Sep. 8, 2013. http://webarchive.nationalarchives.gov.uk/20130123162956/ http://www.defra.gov.uk/statistics/files/defra-stats-foodfarmenviro-climate-climatechange-110729.pdf.

Defra (Department for Environment, Food and Rural Affairs). 2012. UK total nitrogen deposition data. Accessed Sep. 8, 2013. http:// pollutantdeposition.defra.gov.uk/data.

Dewhurst, R. J., and C. Thomas. 1992. Modelling of nitrogen transactions in the dairy cow and their environmental consequences. Livest. Prod. Sci. 31:1-16.

Duvick, D. N. 1986. Plant breeding: Past achievements and expectations for the future. Econ. Bot. 40:289-297.

EMEP/EEA (European Monitoring and Evaluation Programme/European Environment Agency). 2009. Air Pollution Emission Inventory Guidebook. Chapter 4 Agriculture, 4B Manure Management, and 4D Agricultural Soils. Accessed Sep. 8, 2013. http://www.eea. europa.eu/publications/emep-eea-emission-inventory-guidebook2009/\#

Eory, V., C. F. E. Topp, and D. Moran. 2013. Multiple-pollutant costeffectiveness of greenhouse gas mitigation measures in the UK agriculture. Environ. Sci. Pol. 27:55-67.

Erisman, J. W., A. Bleeker, J. Galloway, and M. S. Sutton. 2007. Reduced nitrogen in ecology and the environment. Environ. Pollut. 150:140-149.

European Council. 1991. Directive 91/676/EEC concerning the protection of waters against pollution caused by nitrates from agricultural sources. Off. J. Eur. Union L 375:1-8.

European Parliament and Council. 2000. Directive 2000/60/EC establishing a framework for Community action in the field of water policy. Off. J. Eur. Union L 327:1-73.

Ewing, W. N. 2004. The Feeds Directory. Context Publications, Leicestershire, UK

FAO. 2010. GHG emissions from the dairy sector. Accessed Sep. 8, 2013. http://www.fao.org/docrep/012/k7930e/k7930e00.pdf.

Färe, R. 1992. Productivity gauging with undesirable outputs. Mimeo. Southern Illinois University, Carbondale.

Färe, R., S. Grosskopf, and C. A. K. Lovell. 1994. Production Frontiers. Cambridge University Press, Cambridge, UK.

Färe, R., S. Grosskopf, and D. Tyteca. 1996. An activity analysis model of the environmental performance of firms application to fossilfuel-fired electric utilities. Ecol. Econ. 18:161-175.

Farrell, M. J. 1957. The measurement of productive efficiency. J. R Stat. Soc. A 120:253-290.

Foresight. 2011. The future of food and farming. Final project report The Government Office for Science, London, UK. Accessed Sep. 8, 2013. http://www.bis.gov.uk/assets/foresight/docs/food-andfarming/11-546-future-of-food-and-farming-report.pdf.

Greene, W. 2003. Econometric Analysis. 5th ed. Prentice Hall, Englewood Cliffs, NJ.

Hansson, H. 2008. Are larger farms more efficient? A farm level study of the relationships between efficiency and size on specialized dairy farms in Sweden. J. Agric. Food Sci. 17:325-337.

IPCC. 2006. 2006 Guidelines for national greenhouse gas inventories. Volume 4: Agriculture, forestry and other land use. Intergovernmental Panel on Climate Change (IPCC), Geneva, Switzerland.

IPCC. 2007. Fourth assessment report: Working group 3: Mitigation technologies and practices: Per-area estimates of potential. Accessed Sep. 8, 2013. http://www.ipcc.ch/publications_and_data/ ar4/wg3/en/ch8s8-4-2.html.

Iribarren, D., A. Hospido, M. T. Moreira, and G. Feijoo. 2011. Benchmarking environmental and operational parameters through ecoefficiency criteria for dairy farms. Sci. Total Environ. 409:17861798.

Jarvis, S. C., and H. F. M. Aarts. 2000. Nutrient management from a farming system perspective. Grassl. Sci. Eur. 5:363-373.

Kortelainen, M. 2008. Dynamic environmental performance analysis: A Malmquist index approach. Ecol. Econ. 64:701-715. 
Kuosmanen, T., and M. Kortelainen. 2005. Measuring eco-efficiency of production with data envelopment analysis. J. Ind. Ecol. 9:59-72.

Leach, K. A., D. J. Roberts, and D. L. Swain. 2002. Assessment and improvement of the efficiency of nitrogen use in clover based and fertilizer based dairy systems. 1. Benchmarking using farm gate balances. Biol. Agric. Hortic. 20:143-155.

Lovell, C. A. K. 1993. Production Frontiers and Productive Efficiency. Oxford University Press, Oxford, UK.

Ludena, C. E., T. W. Hertel, P. V. Preckel, K. Foster, and A. Nin. 2007. Productivity growth and convergence in crop, ruminant and non-ruminant production: Measurement and forecasts. Agric. Econ. 37:1-17.

Manevska-Tasevska, G., H. Hansson, and L. Latruffe. 2011. Evaluating the potential effectiveness of rural development programme targets on farms in FYR Macedonia-An efficiency study of grapegrowing family farms. Acta Agric. Scand. C 8:161-172.

Milford, J. B., A. G. Russell, and G. J. McRae. 1989. A new approach to photochemical pollution control: implications of spatial patterns in pollutant responses to reductions in nitrogen oxides and reactive organic gas emissions. Environ. Sci. Technol. 23:1290-1301.

Nousiainen, J., M. Tuori, E. Turtol, and P. Huhtanen. 2011. Dairy farm nutrient management model. 1. Model description and validation. Agric. Syst. 104:371-382.

O'Mara, F. P. 2011. The significance of livestock as a contributor to global greenhouse gas emissions today and in the near future. Anim. Feed Sci. Technol. 166-167:7-15.

ONS (Office for National Statistics). 2012. 2010 Based national population projections: Chapter 2. Accessed Oct. 28, 2012. http:// www.ons.gov.uk/ons/dcp171776_253934.pdf.

Pedersen, W. L., K. Chakrabarty, R. V. Klucas, and A. K. Vidaver. 1978. Nitrogen fixation acetylene reduction associated with roots of winter wheat and sorghum in Nebraska. Appl. Environ. Microbiol. 35:129-135.

Piot-Lepetit, I., D. Vermersch, and R. D. Weaver. 1995. Agriculture's environmental externalities: DEA evidence for French agriculture. Appl. Econ. 29:331-338.

Pitman, R. 1983. Multilateral productivity comparisons with undesirable inputs. Econ. J. 93:883-891.

Pollott, G. E., and M. P. Coffey. 2008. The effect of genetic merit and production system on dairy cow fertility, measured using progesterone profiles and on-farm recording. J. Dairy Sci. 91:3649-3660.

Price, R., S. Thornton, and S. Nelson. 2007. The Social Cost of Carbon and the Shadow Price of Carbon: What They Are, and How To Use Them in Economic Appraisal in the UK. Department for Environment, Food and Rural Affairs, London, UK.

Pryce, J. E., B. L. Nielsen, R. F. Veerkamp, and G. Simm. 1999. Genotype and feeding system effects and interactions for health and fertility traits in dairy cattle. Livest. Prod. Sci. 57:193-201.
Pryce, J. E., M. D. Royal, P. C. Garnsworthy, and I. L. Mao. 2004. Fertility in the high-producing dairy cow. Livest. Prod. Sci. $86: 125-135$.

Roberts, D. J., K. A. Leach, and J. Goldie. 2007. Assessment and improvement of the efficiency of nitrogen use on commercial dairy farms. Int. J. Agric. Sustain. 5:295-304.

SAC (Scottish Agricultural College). 2011. Carbon Calculator v3.11. SAC Consulting, Bush Estate, Penicuik, UK.

Sheane, R., K. Lewis, P. Hall, P. Holmes-Ling, A. Kerr, K. Stewart, and D. Webb. 2010. Identifying opportunities to reduce the carbon footprint associated with the Scottish dairy supply chain-Methodology report. Scottish Government, Edinburgh UK. Accessed Mar. 31, 2012. http://www.scotland.gov.uk/ Publications/2011/02/22152837/0.

Shortall, O. K., and A. B. Barnes. 2013. Greenhouse gas emissions and the technical efficiency of dairy farmers. Ecol. Indic. 29:478-488.

Sjaunja, L. O., L. Baevre, L. Junkkarinene, J. Pedersen, and J. Setala. 1990. A Nordic proposal for an energy corrected milk ECM formula. 27th Session of the International Commission for Breeding and Productivity of Milk Animals, Paris, France.

Sutton, M. A., C. Howard, J. W. Erisman, G. Billen, A. Bleeker, P. Grenfelt, H. van Grinsven, and B. Grizzetti, ed. 2011. The European Nitrogen Assessment. Cambridge University Press, Cambridge, UK.

Tobin, J. 1958. Estimation of relationships for limited dependent variables. Econometrica 26:24-36.

Triboi, E., and A. M. Triboi-Blondel. 2001. Productivity and grain or seed composition: A new approach to an old problem. Eur. J. Agron. 16:163-186.

Tyteca, D. 1996. On the measurement of the environmental performance of firms - A literature review and a productive efficiency perspective. J. Environ. Manage. 46:281-308.

Veerkamp, R. F., G. Simm, and J. D. Oldham. 1994. Effects of interaction between genotype and feeding system on milk production, feed intake, efficiency and body tissue mobilization in dairy cows. Livest. Prod. Sci. 39:229-241.

Yaisawarng, S., and J. D. Klein. 1994. The effects of sulphur dioxide controls on productivity change in the US electric power industry. Rev. Econ. Stat. 76:447-460.

Yu, J., P. Peng, X. Zhang, Q. Zhao, D. Zhy, X. Su, J. Liu, and G. Ao. 2004. Seed specific expression of lysine rich protein $S b 401$ gene significantly increases both lysine and total protein in maize seeds. Mol. Breed. 14:1-7. 